\title{
Alternative Woods in Oenology: Volatile Compounds Characterisation of Woods with Respect to Traditional Oak and Effect on Aroma in Wine, a Review
}

\author{
Ana María Martínez-Gil ${ }^{1, *(0)}$, Maria del Alamo-Sanza ${ }^{1}\left[\right.$, Rubén del Barrio-Galán ${ }^{1}\left(\mathbb{C}\right.$ and Ignacio Nevares ${ }^{2}(\mathbb{C})$ \\ 1 Departamento de Química Analítica, Grupo UVaMOX, Universidad de Valladolid, 34001 Palencia, Spain; \\ maria.alamo.sanza@uva.es (M.d.A.-S.); ruben.barrio@uva.es (R.d.B.-G.) \\ 2 Departamento de Ingeniería Agrícola y Forestal, Grupo UVaMOX, E.T.S. Ingenierías Agrarias, Universidad de \\ Valladolid, 34001 Palencia, Spain; ignacio.nevares@uva.es \\ * Correspondence: anamaria.martinez.gil@uva.es
}

check for updates

Citation: Martínez-Gil, A.M.; del Alamo-Sanza, M.; del Barrio-Galán, R.; Nevares, I. Alternative Woods in Oenology: Volatile Compounds Characterisation of Woods with Respect to Traditional Oak and Effect on Aroma in Wine, a Review. Appl. Sci. 2022, 12, 2101. https:// doi.org/10.3390/app12042101 Academic Editor: Alessandro Genovese

Received: 26 January 2022 Accepted: 12 February 2022 Published: 17 February 2022

Publisher's Note: MDPI stays neutral with regard to jurisdictional claims in published maps and institutional affiliations.

Copyright: (C) 2022 by the authors. Licensee MDPI, Basel, Switzerland. This article is an open access article distributed under the terms and conditions of the Creative Commons Attribution (CC BY) license (https:// creativecommons.org/licenses/by/ $4.0 /)$.

\begin{abstract}
The interest of winemakers to find new woods that can give their wines a special personality and the need for cooperage wood have led to the use of other woods than traditional oak. The aroma of wines is undoubtedly one of the quality factors most valued by consumers. Volatile compounds from wood are transferred to wines during ageing. The type and quantity of aromas in wood depend on several factors, with the species, origin and cooperage treatments, particularly toasting, being very important. The transfer of volatile compounds to the wine depends not only on the wood but also on the wine itself and the type of ageing. This review therefore aims to recapitulate the volatile composition of alternative oenological woods at different cooperage stages and to compare them with traditional woods. It also summarises studies on the effect of wine aromas during ageing both in barrels and with fragments of alternative woods. In summary, it is observed that both woods and wines aged with alternative species of the Quercus genus present the same volatile compounds as traditional ones, but differ quantitatively; however, non-Quercus woods also differ qualitatively.
\end{abstract}

Keywords: Quercus; oak; Q. pyrenaica; cherry; ash; chestnut; mulberry; alternative woods; volatile compounds; wine

\section{Introduction}

Wine is a product that offers a clear example of a saturated market, so winemakers and winegrowers are looking for sustainability and for quality and differentiation to come first. Aroma is undoubtedly one of the most important quality factors, as it provides a profile of identification to wines, as well as being one of the main qualities perceived by consumers, along with colour and taste. Thus, a special emphasis is currently being placed on oenological practices that affect any of these characteristics, whether through agronomic techniques, processes during fermentation or processes during the postfermentation stage.

In oenology, the use of wood during fermentation and/or wine ageing processes is a common practice in most wine-producing regions of the world. For centuries, wood has been used to make barrels. Originally built for the need to transport wine, today they are used because they are capable of improving the three main sensory characteristics (aroma, colour and taste) of wine. Such is the importance that wood has acquired that it has gone from only being part of the barrels at the time of ageing red wines to being present throughout the entire winemaking process, from the grapes to the end of the process, in all types of white, rosé, red, sparkling, sweet wines, etc., and in all types of alternative formats, barrels, vats of different sizes, etc., and even in bottles made of this material [1].

Oak wood has prevailed in the manufacture of barrels mainly because of its abundance and mechanical resistance. Moreover, this wood positively modifies the characteristics of the wine, acquiring a complex aroma as well as stabilising the colour and improving the 
clarification and storage of the wine, gaining fame over time [2-7]. Among the oaks, the most traditional species for wine ageing used are: $Q$. alba (the so-called American oak), $Q$. sessilis (Q. petraea) and Q. robur ( $Q$. pedunculata) (the so-called French oak). The first two species are the most commonly used for wine ageing, while $Q$. robur is very common for Brandy ageing and is less and less used in oenology due to its high ellagitannin content, its high oxygen permeability and its low release of aromatic compounds [4,8,9].

In many wine regions of the world, the use of new oak barrels (or barrels with a limited period of use) increased from the 1990s onwards due to the change that occurred favouring quality. This trend led to an increase in demand for new barrels, resulting in the need to explore new sources of quality cooperage wood [5,10-12]. This gave rise to the exploitation of the same species (Q.petraea and Q.robur), but from different origins, with different countries such as Spain, Hungary, Poland, Russia, Ukraine, Romania and Portugal entering the market. Many of these woods have been used for a long time but have been less studied and characterised. These oaks are of the same species as the "French" ones, but as the structure of the wood and the final chemical composition depend on other factors such as geographical origin and forest management treatments, it is important to study them. Studies of the woods of these species from these geographical origins showed similar characteristics to traditional American and French oaks, being suitable for contact with quality wines [3,13-18], and some even claim that these origins have intermediate characteristics between French and American oaks. With the introduction of these geographical origins, French oaks have been colloquially referred to as European oaks.

On the other hand, the interest in giving wines their own or special personality has led to the proposal of alternative oaks to Q. petraea, Q. robur and Q. alba that can give certain differentiating notes that are positively valued by the consumer. In this context, a market opportunity has opened up for other nontraditional or alternative woods, namely oak species that have not been used in cooperage such as $Q$. faginea Lam., $Q$. pyrenaica Wild., Q. farnetto Ten, Q. oocarpa Liebm. and Q. humboldtii Bonpl and others less known such as $Q$. serrata, $Q$. mongolica or $Q$. denta $[5,12]$. In addition, the cooperage industry has been forced to offer a wider range of products from non-oak woods, such as Robinia pseudoacacia L. (false acacia), Castanea sativa Mill. (chestnut), Prunus avium L. and Prunus cereasus L. (cherry), Fraxinus excelsior L. and Fraxinus americana L. (European and American ash, respectively) [12,19-24]. In fact, many of these woods had been used for many years, but most of them had been neglected in terms of cooperage use. However, due to the continuous quest to differentiate some wines from others, they have been given another chance. Others have been around for centuries, such as chestnut, but advances in the knowledge of wood, processes and ageing have led to the production of higher quality contact wood for wine. As a result, many producers are opting for local woods and are using barrels made from woods other than Quercus [5].

The components that are released from the wood to the wine are called the "extractable fraction" and represent approximately $10 \%$ of the dry wood weight. These compounds are difficult to classify due to their varied nature. Ellagitannins are the most abundant, but there are also others with different chemical structures such as low molecular weight phenols and volatile compounds. Some of these compounds are the origin of many of the interesting organoleptic characteristics found in wines that have been in contact with wood and their presence has led winemakers to increasingly use wood throughout the winemaking process $[4,5,11,12]$.

Volatile compounds from oak transferred to wine are of great sensory importance because they contribute aromatic notes of "vanilla", "sweet", "almond", "wood", "coconut", "spice", "smoked" and "toasted" (Table 1), increasing its complexity [25,26]. The volatile compounds generally found in traditional oaks are those also found in alternative oaks and other woods. Despite this, the genus and species of wood affects the aromatic profile and there are compounds such as volatile phenols, lactones, furanic compounds, aldehydes and others that can differentiate them and, above all, provide quantitative and qualitative differences [13,24,27-29]. A clear example is the long-known generalisation with traditional oaks, where the highest amount of cis- $\beta$-Methyl- $\gamma$-octalactone lactone (cis lactone) is associated with Q. alba $[4,18,30]$. 
Table 1. Information on some of the main and most-studied volatile compounds in wood and wine aged with them.

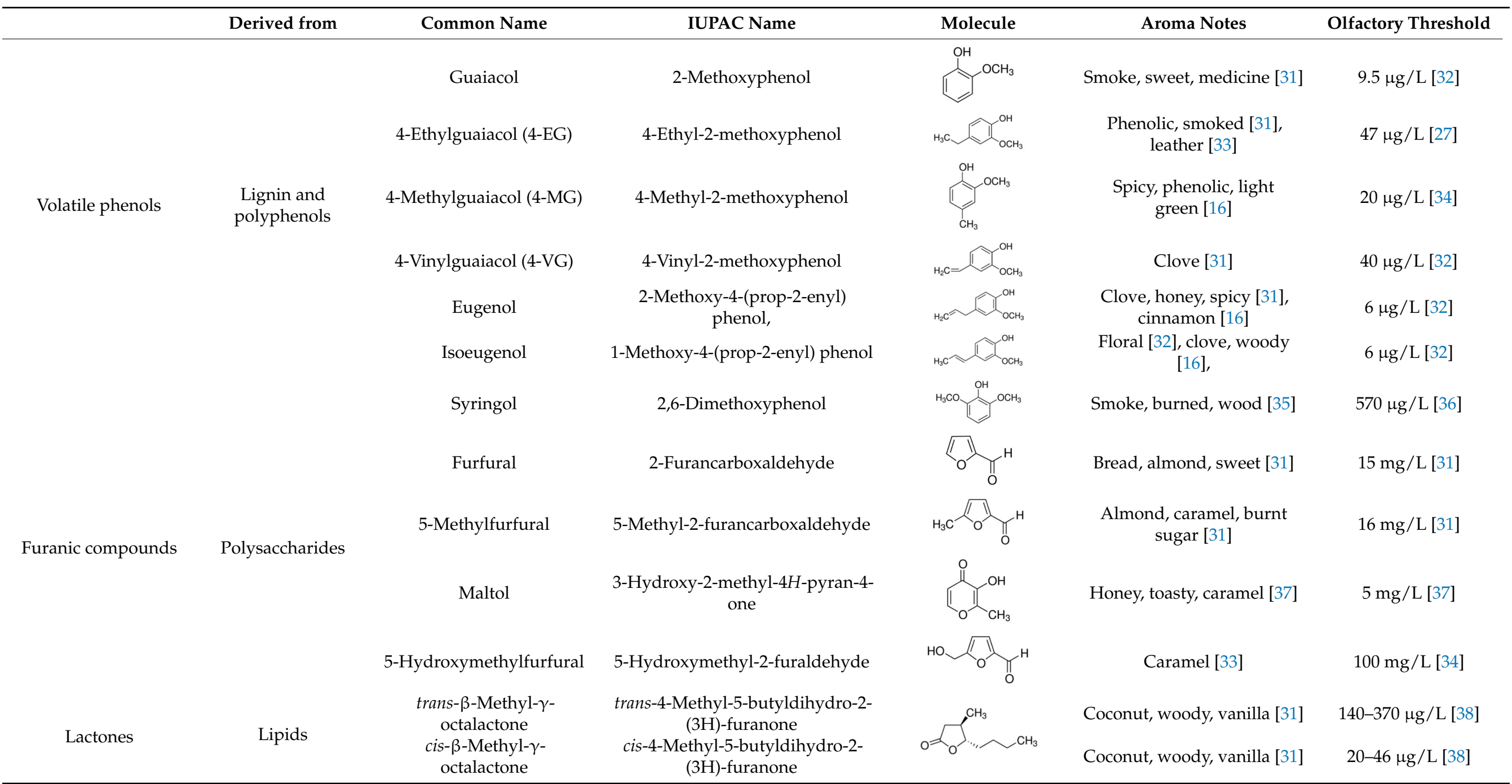


Table 1. Cont.

\begin{tabular}{|c|c|c|c|c|c|c|}
\hline & Derived from & Common Name & IUPAC Name & Molecule & Aroma Notes & Olfactory Threshold \\
\hline \multirow{4}{*}{$\begin{array}{c}\text { Phenolic } \\
\text { aldehydes/Phenyl } \\
\text { ketones }\end{array}$} & \multirow{4}{*}{ Lignin } & Vanillin & $\begin{array}{l}\text { 4-Hydroxy-3- } \\
\text { methoxybenzaldehyde }\end{array}$ & & Vanilla [31] & $1000 \mu \mathrm{g} / \mathrm{L}[32]$ \\
\hline & & Syringaldehyde & $\begin{array}{c}\text { 4-Hydroxy-3,5- } \\
\text { dimethoxybenzaldehyde }\end{array}$ & & Vanilla [31] & 50 mg/L [39] \\
\hline & & Acetovanillone & $\begin{array}{l}\text { 1-(4-hydroxy-3- } \\
\text { methoxyphenyl)ethanone }\end{array}$ & & Vanilla [31] & $1000 \mu \mathrm{g} / \mathrm{L}$ [39] \\
\hline & & Butyrovanillone & $\begin{array}{l}\text { 1-(4-Hydroxy-3-methoxyphenyl) } \\
\text { butanone }\end{array}$ & & & \\
\hline
\end{tabular}


Numerous factors influence the concentrations of volatile compounds found in wood or in wine aged with it, one of the most important being the wood toasting, although there are others, such as silvicultural treatments to the trees and the type of wood drying [40-43]. The toasting of wood increases the quantity and complexity of the compounds yielded by the wood to the wine, as it induces the formation of new volatile compounds by thermal degradation of the wood or increases the existing ones. Depending on the temperature and exposure time, toasting can be light, medium or heavy. The temperature, time and toasting cooperage method (fire or hot air convection) also affect wood aroma compounds [13,27,43-46]. Volatile phenols, phenolic aldehydes and phenylketones come from the thermodegradation of lignin [41]. These compounds mainly give the wine smoky, woody, vanilla and spicy aromas (Table 1). Furanic compounds come from the thermal degradation of polysaccharides [44], providing aromas of toasted almond, nuts, caramel, burnt sugar, bread and sweets (Table 1). This family of compounds enhances the aroma of oak and accentuates that of other compounds such as lactones $[47,48]$. The two isomers $\beta$-Methyl- $\gamma$-octalactone (cis lactone and trans lactone) are mainly formed during toasting by dehydration of 2-methyl-3-(3,4-dihydroxy-5-methoxybenzo)-octanoic acid, [49] giving the wine woody and coconut aromas (Table 1). It should be remembered that even if a compound does not exceed the minimum concentration marked by the perception threshold for its aroma to be expressed, molecules interact with each other, enhancing the aroma of another compound or giving aromatic nuances $[47,50]$. Other factors that influence the content of these aromas in the final wines are the contact time of the wine with the wood, the wood-wine ratio, whether the wood is new or has been previously used with other wines [51-53] and the type of contact (barrels or wood's pieces) [40,52,54,55], among others. In addition to all the aforementioned factors, the concentration of volatile compounds from wood in the wine depends on the grape variety and maturity, as each wine has a different capacity to extract these compounds from woods [29,56,57].

The aim of this review was to recapitulate and compare the composition in volatile compounds studied by gas chromatography of woods other than those traditionally used in oenology (Q. alba, Q. petraea and Q. robur), at each of the different cooperage stages (green wood, after being seasoned and after toasting), and of the wines that have been in contact with them both in barrels and/or with pieces of wood.

\section{Volatile Wood Composition}

This section summarises the volatile composition of the different alternative woods. The woods studied from the Quercus genus were Q. pyrenaica, Q. faginea and Q. humboldtii and from non-Quercus species, Robinia pseudoacacia (acacia), Castanea sativa (chestnut), Prunus avium (cherry), Fraxinus excelsior (European ash), Fraxinus americana (American ash) and Morus alba (mulberry). Volatile compounds in green, dried and toasted wood are represented in Tables $2-4$, respectively. In green wood, aroma studies were found in $Q$. pyrenaica species. However, mulberry was characterised in dried wood and Q. humboldtii in toasted wood. If traditional woods were analysed in the works on alternative woods, they were also included. Most of the studies were carried out after toasting because this is the process that most affects the volatile composition of the wood. The compounds represented belonged to very different chemical families, such as volatile phenols, lactones, furanic compounds and phenolic aldehydes. Their concentrations covered a very wide range, reaching up to $59 \mu \mathrm{g} / \mathrm{g}$ in green wood (Table 2), $80.9 \mu \mathrm{g} / \mathrm{g}$ in dried wood (Table 3) and even up to more than $5078 \mu \mathrm{g} / \mathrm{g}$ in toasted wood (Table 4). 
Table 2. Volatile compounds expressed as $\mu \mathrm{g} / \mathrm{g}$ of wood found in extracts of green woods of different botanical origins.

\begin{tabular}{|c|c|c|c|c|c|c|c|c|c|c|c|c|c|c|c|c|c|c|}
\hline & \multicolumn{7}{|c|}{ Volatile Phenols } & \multicolumn{4}{|c|}{ Furanic Compounds } & \multicolumn{3}{|c|}{ Lactones } & \multicolumn{4}{|c|}{$\begin{array}{c}\text { Phenolic } \\
\text { Aldehydes/Phenyl } \\
\text { Ketones }\end{array}$} \\
\hline Species & 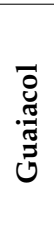 & $\begin{array}{l}0 \\
4 \\
4\end{array}$ & $\sum_{j}^{U}$ & $\sum_{4}^{1}$ & 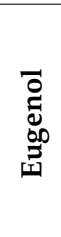 & 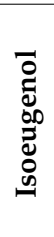 & 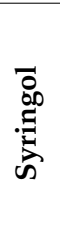 & $\underset{⿱ 乛 龰}{己}$ & $\sum_{\text {in }}^{M}$ & $\frac{\overline{0}}{\sum^{\pi}}$ & 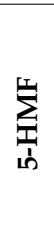 & $\begin{array}{l}\frac{1}{3} \\
2 \\
\vdots \\
\Sigma\end{array}$ & $\frac{1}{3}$ & 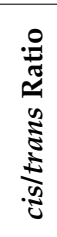 & 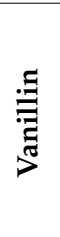 & 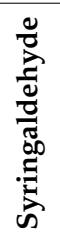 & 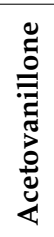 & 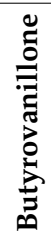 \\
\hline
\end{tabular}

\begin{tabular}{|c|c|c|c|c|c|c|c|c|c|c|c|c|c|c|c|c|c|c|}
\hline $\begin{array}{l}\text { Alternative woods } \\
\text { Q. pyrenaica }\end{array}$ & & & & & & & & & & & & & & & & & & \\
\hline $\begin{array}{l}\text { Gata/Peña de } \\
\text { Francia [58] }\end{array}$ & 0.18 & 0.06 & 0.51 & 0.61 & 5.2 & 0.61 & 0.47 & 2.6 & 0.22 & 0.28 & 3.7 & 4.8 & 36 & 7.4 & 3.4 & 4.4 & 0.38 & 0.06 \\
\hline $\begin{array}{l}\text { Gata/Peña de } \\
\text { Francia }[11,59]\end{array}$ & 0.21 & 0.07 & 0.76 & 0.67 & 5.7 & 0.71 & 0.51 & 2.4 & 0.25 & 0.27 & 3.8 & 6.4 & 59 & 12 & 3.6 & 5.1 & 0.50 & 0.08 \\
\hline Gudarrama $[11,59]$ & 0.16 & 0.02 & 0.36 & 0.64 & 2.3 & 0.28 & 0.17 & 2.4 & 0.19 & 0.24 & 1.7 & 0.84 & 15 & 17 & 3.8 & 5.4 & 0.26 & 0.04 \\
\hline $\begin{array}{l}\text { Cantábrica mountain } \\
\text { range }[11,59]\end{array}$ & 0.24 & 0.14 & 0.52 & 0.72 & 1.5 & 0.26 & 0.23 & 1.4 & 0.33 & 0.23 & 2.7 & 7.3 & 27 & 7.5 & 2.4 & 4.8 & 0.24 & 0.04 \\
\hline Sistema Ibérico [59] & 0.16 & 0.02 & 0.39 & 0.52 & 1.6 & 0.32 & 0.21 & 1.9 & 0.41 & 0.24 & 1.7 & 29 & 14 & 4.9 & ne & ne & 0.20 & 0.03 \\
\hline Aliste-Margarita [11] & 0.12 & 0.07 & 0.08 & 0.54 & 0.73 & 0.24 & 0.34 & 0.9 & 0.22 & 0.17 & 3.2 & 2.8 & 12 & 3.8 & 1.5 & 3.5 & 0.21 & 0.02 \\
\hline $\begin{array}{l}\text { North of Sistema } \\
\text { Ibérico [11] }\end{array}$ & 0.13 & 0.04 & 0.49 & 0.86 & 2.2 & 0.44 & 0.31 & 1.7 & 0.24 & 0.23 & 2.9 & 10 & 18 & 4.9 & 4.4 & 14 & 0.35 & 0.05 \\
\hline $\begin{array}{l}\text { Gredos and Sierra de } \\
\text { Avila [11] }\end{array}$ & 0.09 & 0.04 & 0.07 & 0.39 & 0.55 & 0.26 & 0.07 & 0.57 & 0.24 & 0.19 & 1.7 & 0.54 & 1.7 & 2.5 & 1.7 & 3.0 & 0.16 & 0.03 \\
\hline
\end{tabular}

\section{Traditional Quercus}

\begin{tabular}{lllllllllllllllllll}
\hline Q. petraea [58] & 0.09 & 0.01 & 0.06 & 0.39 & 2.1 & 0.18 & 0.07 & 1.2 & 0.22 & 0.24 & 0.63 & 18 & 37 & 3.9 & 2.2 & 2.7 & 0.16 & 0.56 \\
\hline
\end{tabular}

Acronyms: 4-EG: 4-Ethylguaiacol; 4-MG: 4-Methylguaiacol; 4-VG: 4-Vinylguaiacol; trans WL: trans lactone (trans- $\beta$-Methyl- $\gamma$-octalactone); cis WL: cis lactone (trans- $\beta$-Methyl- $\gamma$-octalactone); ne: analysed by HPLC.

\section{Q. pyrenaica Wild}

The most studied volatile composition has been in Q. pyrenaica wood, in green wood [11,58,59], dry wood [23,58,60-64] and toasted wood [6,20,40,62-67] (some not considered in the table $[20,62,67])$.

Table 2 shows the volatile composition of green $Q$. pyrenaica wood from different origins. It can be seen that Spanish wood from Gata/Peña de Francia forest was the most aromatic while wood from Gredos and Sierra de Ávila forest was the poorest. The most abundant compound was cis lactone, the wood from Gata/Peña de Francia forest being the one with the highest contents, even higher [59] or similar [58] to Q. petraea. In most of the sources, the content of the cis lactone isomer was higher than that of the trans lactone isomer, which is usually observed in traditional oaks. This trans lactone isomer in $Q$. pyrenaica woods was, in general, lower than in $Q$. petraea. Therefore, it is observed that the sum of lactones in Q. petraea $(55.3 \mu \mathrm{g} / \mathrm{g})$ is higher than in $Q$. pyrenaica wood $(30.7 \mu \mathrm{g} / \mathrm{g})$ (Figure 1a). The wood of $Q$. pyrenaica showed a high content of volatile phenols (Figure 1a), as most of these compounds had higher concentrations than those found in Q. petraea (Table 2). The green wood of this species showed higher furanic compounds contents than those observed in Q. petraea wood, 4.9 vs. $2.3 \mu \mathrm{g} / \mathrm{g}$ (Figure 1a). This is especially due to $5-\mathrm{HMF}$, as the contents in $Q$. pyrenaica, even in the poorest source $(1.7 \mu \mathrm{g} / \mathrm{g})$ is almost three times higher than in $Q$. petraea wood $(0.63 \mu \mathrm{g} / \mathrm{g})$. The green wood of $Q$. pyrenaica also had elevated phenolic aldehydes and acetovanillone contents (Table 2 and Figure 1a), being generally higher than $Q$. petraea. However, the green wood of $Q$. pyrenaica was rather low in butyrovanillone, regardless of its origin (Table 2). 
a)

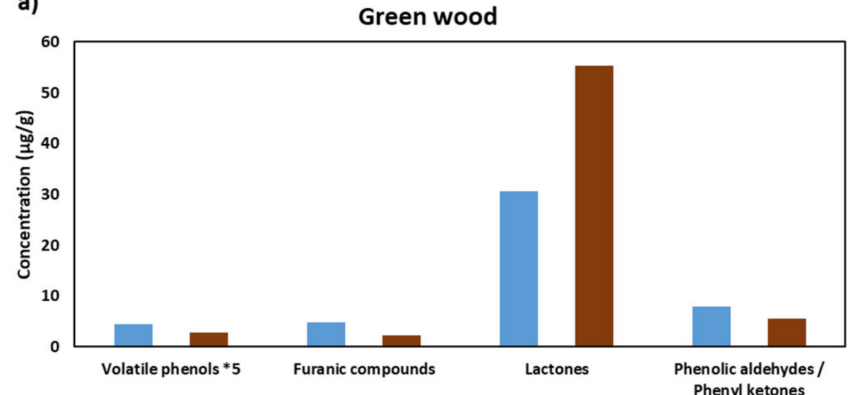

c)

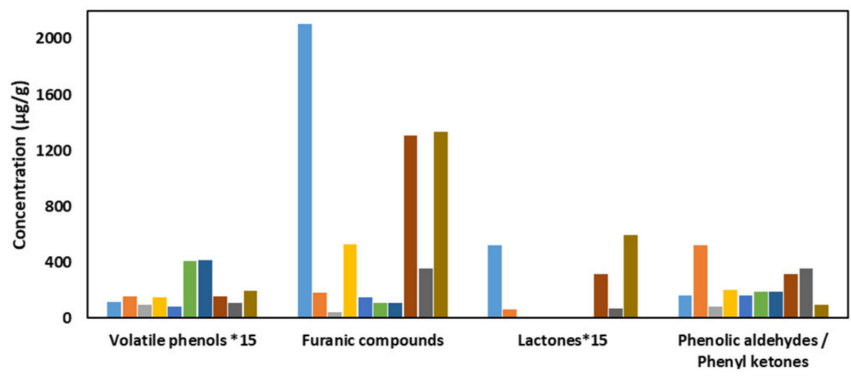

e)

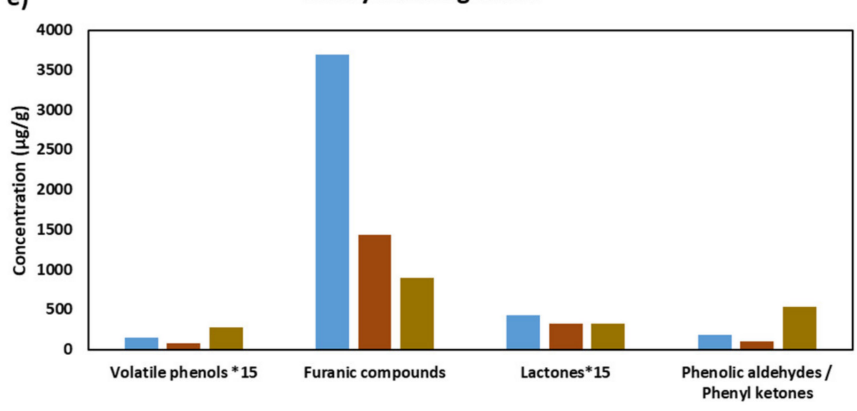

b)

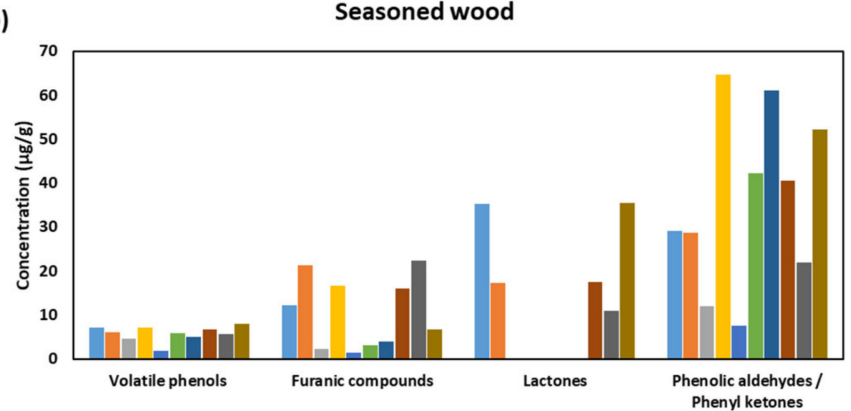

d)

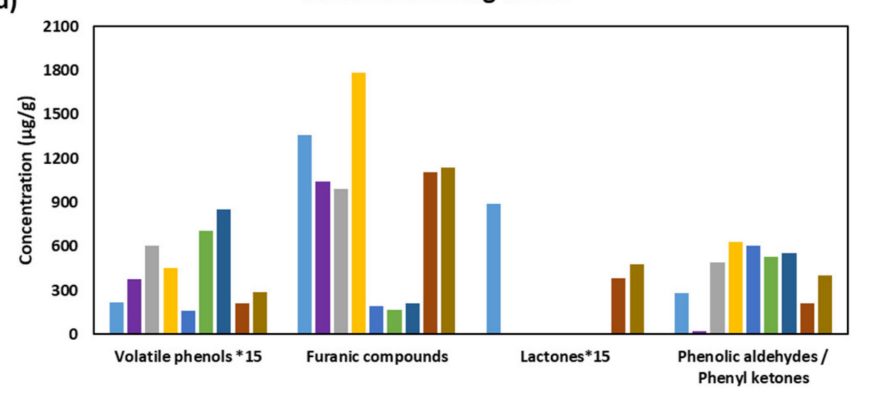

Figure 1. Graphical representation of the averages of the sum of the compounds in wood volatile phenols, furanic compounds, lactones and phenolic aldehydes/phenyl ketones by wood species, after the different cooperage treatments: (a) green, without treatment; (b) seasoned (carried out in oven and in open air); (c) light-toasted (light toasting, $190^{\circ} \mathrm{C}$ for $10 \mathrm{~min}, 160-170^{\circ} \mathrm{C}$ for $20 \mathrm{~min}$ and for $35 \mathrm{~min}$ ); (d) medium-toasted (medium toasting, $180^{\circ} \mathrm{C}$ for $45 \mathrm{~min}, 200{ }^{\circ} \mathrm{C}$ for $15 \mathrm{~min}$ and $35 \mathrm{~min}$, $210{ }^{\circ} \mathrm{C}$ for $20 \mathrm{~min}$ and $45 \mathrm{~min}$, and medium plus toasting); (e) heavy-toasted (heavy toasting and $250-260{ }^{\circ} \mathrm{C}$ for $\left.27 \mathrm{~min}\right)$.

The origin and preparation of the wood have a great influence on the volatile composition, which makes the comparison between different studies difficult. Therefore, it was only possible to see how drying affects it in the study by Cadahía et al., 2007 [58], as it analysed the same woods when green (Table 2) and with different seasoning times (12, 18 and 24 months) (Table 3). The seasoning time increased the content of all compounds, although the fluctuations were probably due to the formation from their precursors but also to the removal by leaching or evaporation [41,68,69], as can be observed for volatile phenols, phenyl ketones and lactones (Table 3). However, phenolic aldehydes after 12 months of seasoning increased by $4 \mu \mathrm{g} / \mathrm{g}$ and subsequently showed a decrease of up to $2.6 \mu \mathrm{g} / \mathrm{g}$ at 24 months. The highest contents of furanic compounds were found after 18 months of seasoning. Oak $Q$. pyrenaica wood undergoes changes during the drying process, which may seem limited compared to the toasting process as well as traditional woods [58].

The dry wood of $Q$. pyrenaica, as in green wood, showed higher cis lactone than trans lactone (Table 3). In general, both isomers were found in concentrations within the range of traditional oaks. The seasoned wood from Gata/Peña de Francia forest, an origin that already showed a high concentration when green (Table 2), stood out for its high cis lactone 
content, even higher than that of Q. alba (Table 3). Meanwhile, the wood from the Salamanca region (Spain) had the highest trans lactone content (33.8 $\mu \mathrm{g} / \mathrm{g}$ ) [23], being six times higher than the other Q. pyrenaica woods and even more than twice as high as the traditional ones. However, trans lactone was not detected in wood from the Gerês forest in Portugal [63]. The average lactone concentration of seasoned wood from Q. pyrenaica was very similar to $Q$. alba and higher than Q. petraea (Figure $1 \mathrm{~b}$ ). The highest vanillin contents were found after oven drying in both $Q$. pyrenaica and traditional woods. Oven-dried and generally air-seasoned woods of $Q$. pyrenaica had lower vanillin concentrations than $Q$. petraea and $Q$. alba, with the exception of those from the Salamanca and Alava provinces in Spain. The content of volatile phenols and furanic compounds in the seasoned Q. pyrenaica woods was between the values of $Q$. petraea and $Q$. alba (Figure $1 \mathrm{~b}$ ). It was observed that the concentration of eugenol, isoeugenol and 5-HMF in some seasoned woods of $Q$. pyrenaica were even higher than those found in traditional woods (Table 3). Alañon et al., 2012 [61] placed the dry wood of $Q$. pyrenaica aromatically closer to $Q$. alba, especially because of the low content of furanic compounds, which did not correlate with that observed by most authors, and the high content of lactones. These authors [61] indicated that this species is very rich in terpenic and norisoprenoid compounds, with particularly higher levels of $\alpha$-terpineol and methyl dihydrojasmonate than traditional Quercus and chestnut woods.

Alañón et al., 2011 [60] studied the influence of geographical location on the aroma of dried wood and found that altitude was the most influential parameter, with geographical location also having an important impact on extraction. Thus, higher altitudes and/or clay-textured soils showed lower concentrations of some volatiles [60]. Therefore, the content of all volatile compounds in Ourense's forest wood was lower than in the wood from forests from Lugo and Pontevedra (Spain) [60].

On the other hand, the way Q. pyrenaica wood was dried, in a traditional or accelerated way, had less influence on the volatile composition than the size of the piece of wood and the intensity of the toasting [40]. This is probably due to the fact that this wood undergoes less volatile compound formation than traditional wood during this drying process. Jordao et al., 2005 [63] showed that Q. pyrenaica wood was poor in total volatile composition after being seasoned, presenting about 30-40 $\mu \mathrm{g} / \mathrm{g}$ compared to more than $50 \mu \mathrm{g} / \mathrm{g}$ for the traditional ones. However, after toasting, Q. pyrenaica wood showed the highest contents [63] at about $5000 \mu \mathrm{g} / \mathrm{g}$ after toasting at $250-260^{\circ} \mathrm{C}$ and $5979-8332 \mu \mathrm{g} / \mathrm{g}$ after toasting at $160-170{ }^{\circ} \mathrm{C}$, while in the traditional ones it was $1161-2153 \mu \mathrm{g} / \mathrm{g}$ and $2201-4794 \mu \mathrm{g} / \mathrm{g}$, respectively. The difference after toasting of this species compared to the traditional ones was mainly due to furfural, 5-HMF and vanillin [63]. Fernandez de Simón et al., 2010 [66] also observed a higher concentration of furanic compounds in $Q$. pyrenaica woods together with furaneol and cis lactone; however, vanillin concentrations in this study were lower than traditional ones. However, Cadahía et al., 2003 [64] observed that the concentrations of all compounds in Q. pyrenaica after toasting were between the concentrations of traditional oaks, closer to those of $Q$. petraea wood.

The level of toasting in Q. pyrenaica, as in traditional oaks, has a great influence on the concentration of many of the volatiles. This process increases the content by hydrothermolysis and pyrolysis reactions; however, if the temperature increases a lot and is maintained for a long time, the volatile compounds are degraded [40,64,66,70]. Jordao et al., 2005 [63] showed that almost all aromas were higher after toasting at $160-170{ }^{\circ} \mathrm{C}$ than after toasting at $250-260{ }^{\circ} \mathrm{C}$. Similar results were shown by Fernandez de Simón et al., 2010 [66], where it was seen that aromas were formed as the toasting was increased as in traditional woods, but with a very high toasting temperature, they were degraded, especially with heavy toasting. 
Table 3. Volatile compounds expressed as $\mu \mathrm{g} / \mathrm{g}$ of wood found in extracts of seasoned woods of different botanical origins.

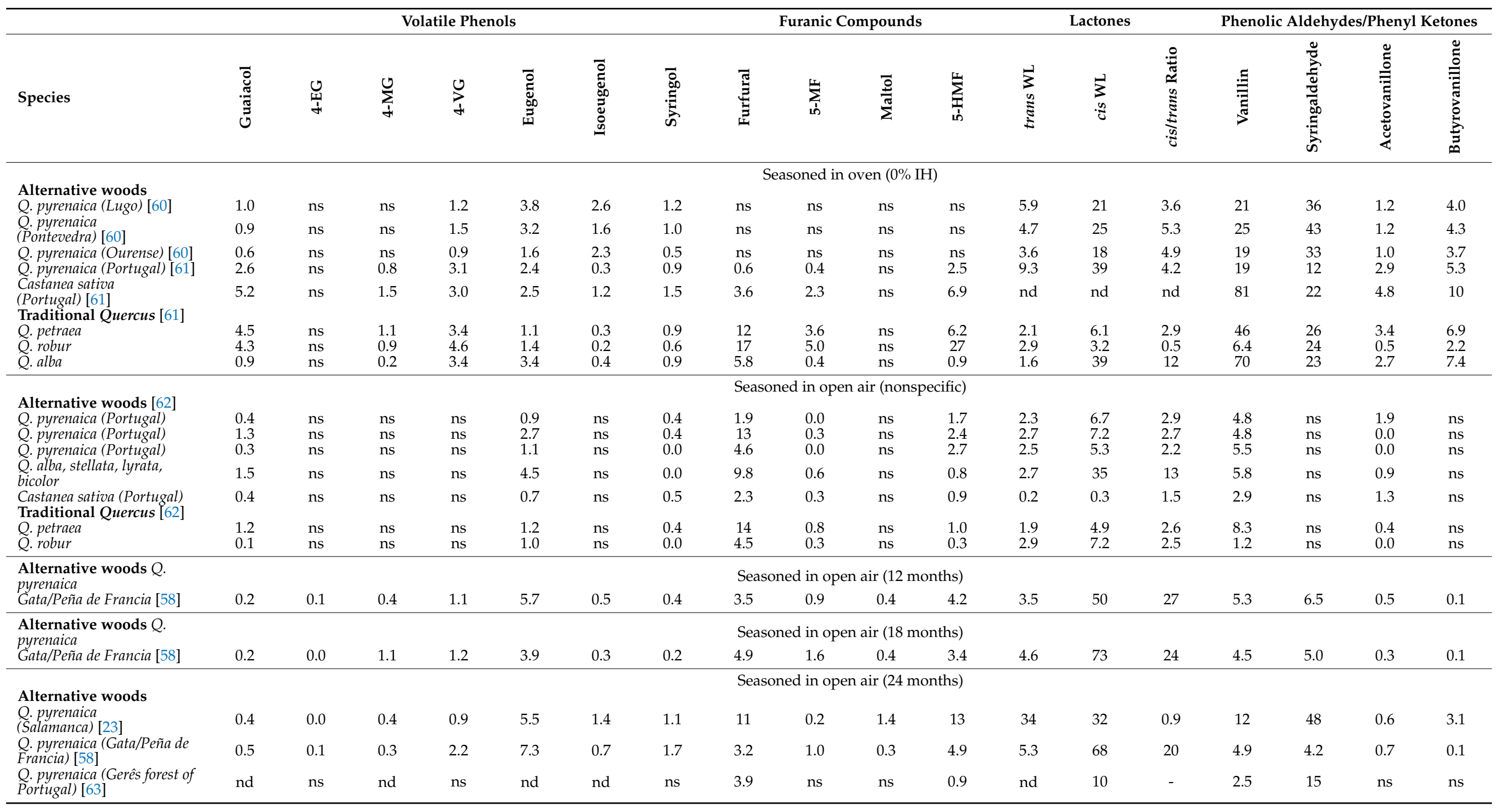


Table 3. Cont.

\begin{tabular}{|c|c|c|c|c|c|c|c|c|c|c|c|c|c|c|c|c|c|c|}
\hline \multirow[b]{2}{*}{ Species } & \multicolumn{7}{|c|}{ Volatile Phenols } & \multicolumn{4}{|c|}{ Furanic Compounds } & \multicolumn{3}{|c|}{ Lactones } & \multicolumn{4}{|c|}{ Phenolic Aldehydes/Phenyl Ketones } \\
\hline & 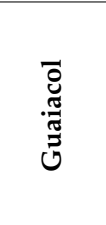 & U্ & 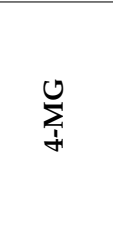 & $\underset{d}{J}$ & $\begin{array}{l}\overrightarrow{0} \\
\overrightarrow{0} \\
\stackrel{\Phi}{\Phi} \\
\vec{\Phi}\end{array}$ & 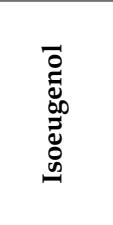 & $\begin{array}{l}\overrightarrow{8} \\
\text { 品 } \\
\text { 品 }\end{array}$ & 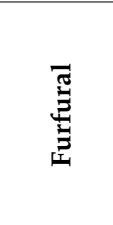 & $\sum_{i}^{H}$ & 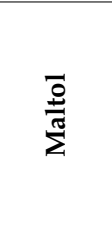 & $\sum_{\text {它 }}^{\mid}$ & 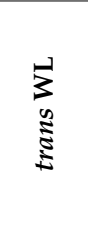 & $\frac{1}{3}$ & 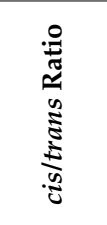 & 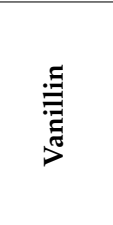 & 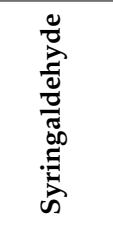 & 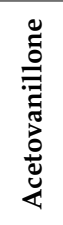 & 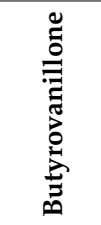 \\
\hline $\begin{array}{l}\text { Q. pyrenaica (Guarda forest } \\
\text { of Portugal) [63] }\end{array}$ & nd & ns & nd & ns & nd & nd & ns & 4.5 & ns & ns & 1.3 & 8.3 & 5.3 & 0.6 & 1.6 & 17 & ns & ns \\
\hline Robinia pseudoacacia [23] & 0.4 & 0.1 & 0.0 & 0.4 & 0.1 & 1.0 & 0.8 & 0.5 & 0.0 & 0.9 & 0.2 & nd & nd & - & 1.7 & 6.0 & 0.2 & 0.7 \\
\hline Castanea sativa [23] & 0.1 & 0.0 & 0.1 & 0.3 & 2.0 & 2.2 & 0.1 & 5.5 & 0.1 & 1.1 & 14 & nd & nd & - & 24 & 53 & 0.5 & 2.0 \\
\hline Castanea sativa [65] & 0.2 & ns & 0.2 & ns & 4.5 & 2.4 & 0.3 & 6.7 & 0.2 & 2.0 & 21 & ni & ni & - & 17 & 38 & 0.4 & 1.9 \\
\hline Prunus avium [23] & 0.2 & 0.0 & 0.0 & 0.3 & 0.1 & 0.0 & 0.4 & 0.5 & 0.0 & 0.4 & 0.2 & nd & nd & - & 1.1 & 2.6 & 0.2 & 0.4 \\
\hline Prunus avium [65] & 0.5 & ns & 0.1 & ns & 0.1 & 0.6 & 1.5 & 0.7 & 0.1 & 0.5 & 0.5 & ni & ni & - & 2.4 & 6.9 & 0.3 & 1.0 \\
\hline $\begin{array}{l}\text { Fraxinus excelsior } \\
\text { (Europe) [23] }\end{array}$ & 0.1 & nd & 0.1 & 0.4 & 0.2 & 1.3 & 0.2 & 0.8 & 0.0 & 0.2 & 0.9 & nd & nd & - & 7.3 & 45 & 0.2 & 0.6 \\
\hline $\begin{array}{l}\text { Fraxinus excelsior } \\
\text { (Europe) [65] }\end{array}$ & 0.1 & ns & 0.2 & ns & 0.6 & 7.7 & 0.6 & 0.5 & 0.1 & 0.5 & 3.3 & ni & ni & - & 10 & 20 & 0.4 & 1.3 \\
\hline $\begin{array}{l}\text { Fraxinus americana } \\
\text { (American) }[23]\end{array}$ & 0.1 & 0.02 & 0.8 & 0.6 & 0.4 & 2.4 & 0.2 & 1.2 & 0.0 & 0.8 & 1.6 & nd & nd & - & 15 & 51 & 0.4 & 2.0 \\
\hline $\begin{array}{l}\text { Fraxinus americana } \\
\text { (American) }[65]\end{array}$ & 0.2 & $\mathrm{~ns}$ & 1.2 & ns & 0.9 & 2.1 & 0.9 & 1.3 & 0.1 & 0.9 & 2.0 & ni & ni & - & 14 & 37 & 0.9 & 2.4 \\
\hline $\begin{array}{l}\text { Traditional Quercus } \\
\text { Q. petraea }[23,58,63]\end{array}$ & nd-1.3 & nd- 0.0 & nd-0.6 & $0.2-1.0$ & $1.3-6.5$ & $0.7-4.3$ & $0.1-0.2$ & $3.4-7$ & $0.1-0.2$ & $0.2-0.8$ & $0.3-4$ & $5-15$ & $14-56$ & $1.7-9$ & $2-12$ & $2.7-47$ & 0.4 & $1.4-1.9$ \\
\hline
\end{tabular}

\section{Alternative woods}

northern Italy [71]

Robinia pseudoacacia

Castanea sativa

Prunus avium

Mulberry

Seasoned in open air (24-36 months)

Traditional Quercus [71]
France

\begin{tabular}{|c|c|c|c|c|c|c|c|c|c|c|c|c|c|c|c|c|}
\hline ns & ns & nd & nd & ns & nd & ns & ns & ns & ns & ns & ns & ns & 1.7 & 10 & ns & ns \\
\hline ns & ns & nd & 0.7 & ns & nd & ns & ns & ns & ns & ns & ns & ns & 5.2 & 4.2 & ns & ns \\
\hline nd & ns & nd & nd & ns & 0.1 & ns & ns & ns & ns & ns & ns & ns & 0.1 & 0.4 & ns & ns \\
\hline 0.0 & ns & nd & nd & ns & nd & ns & ns & ns & ns & ns & ns & ns & 0.1 & 0.5 & ns & ns \\
\hline ns & ns & 0.1 & 2.0 & ns & 0.0 & ns & ns & ns & ns & ns & ns & ns & 2.0 & 9.3 & ns & ns \\
\hline
\end{tabular}

\section{Alternative woods [64]}

Q. pyrenaica (Alava)

Q. faginea (Alava)

Q. petraea

$0.1+2=0$

Seasoned in open air (36 months)

\begin{tabular}{|c|c|c|c|c|c|c|c|c|c|c|c|c|c|c|c|c|c|}
\hline $\begin{array}{l}0.1 \\
0.3\end{array}$ & $\begin{array}{l}0.0 \\
0.2\end{array}$ & $\begin{array}{l}0.5 \\
0.5\end{array}$ & $\begin{array}{l}2.0 \\
1.1\end{array}$ & $\begin{array}{l}2.3 \\
2.0\end{array}$ & $\begin{array}{l}0.4 \\
0.4\end{array}$ & $\begin{array}{l}0.3 \\
1.6\end{array}$ & $\begin{array}{l}20 \\
18\end{array}$ & $\begin{array}{l}1.5 \\
1.8\end{array}$ & $\begin{array}{l}0.3 \\
0.4\end{array}$ & $\begin{array}{l}3.9 \\
1.5\end{array}$ & $\begin{array}{l}4.6 \\
1.7\end{array}$ & $\begin{array}{l}18 \\
16\end{array}$ & $\begin{array}{l}3.7 \\
11\end{array}$ & $\begin{array}{l}11 \\
11\end{array}$ & $\begin{array}{l}15 . \\
10\end{array}$ & $\begin{array}{l}0.7 \\
1.5\end{array}$ & $\begin{array}{l}2.4 \\
6.6\end{array}$ \\
\hline & 0. & -0.4 & -1 & $6-3.2$ & $.2-0$ & $.2-1$ & -20 & $1.5-1$ & 4 & 6 & 0.1 & 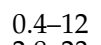 & & 14 & 9 & 1.2 & \\
\hline & 0.1 & $\begin{array}{c}0.2-0.7 \\
0.7\end{array}$ & $\begin{array}{c}1.0-1.3 \\
0.5\end{array}$ & $\begin{array}{c}1.1-1.6 \\
57\end{array}$ & $\begin{array}{l}0.3 \\
0.3\end{array}$ & $\begin{array}{l}0.2 \\
0.2\end{array}$ & $\begin{array}{c}8.9-11 \\
4.0\end{array}$ & $\begin{array}{c}1.1-2.0 \\
0.3\end{array}$ & $\begin{array}{c}0.3-0.4 \\
0.2\end{array}$ & $\begin{array}{l}0.8-2.7 \\
1.8\end{array}$ & $\begin{array}{l}3.4-4.0 \\
3.5\end{array}$ & $2.8-23$ & $4.0-7.0$ & $\begin{array}{l}9.3-16 \\
79\end{array}$ & $\begin{array}{c}14-18 \\
16\end{array}$ & .7-1.0 & $1.7-2.5$ \\
\hline
\end{tabular}

Acronyms: 4-EG: 4-Ethylguaiacol; 4-MG: 4-Methylguaiacol; 4-VG: 4-Vinylguaiacol; trans WL: trans lactone (trans- $\beta$-Methyl- $\gamma$-octalactone); cis WL: cis lactone (trans- $\beta$-Methyl- $\gamma$ octalactone); ns: not studied; ni: not identified; nd: not detected. 
There is much variability among the studies carried out, although, in general, it could be said that the toasted wood of Q. pyrenaica is rich in certain compounds, such as cis lactone, eugenol, 4-VG and furanic compounds. The rest of the compounds are usually present in similar concentrations to traditional woods, as is the case of most volatile phenols, phenolic aldehydes and phenyl ketones (Table 4 and Figure 1). Figure 1 shows that the lactone content in Q. pyrenaica is similar to (Figure 1c) or higher (Figure 1d,e) than Q. alba and always higher than $Q$. petraea. Furthermore, regardless of toasting, a higher content of furanic compounds was observed in the wood of Q. pyrenaica than in the traditional ones (Figure 1).

\section{Quercus faginea Lam}

Only one work was found on the volatile composition of Q. faginea wood [64], studied both after seasoning and toasting. This wood showed the same compounds and in similar concentrations to the wood of traditional oaks, although butyrolactone, hydroxybenzaldehyde and 1H-pyrrole-2-carboxaldehyde were not detected in the seasoned wood, but were detected in the toasted wood. The seasoned wood of $Q$. faginea showed higher concentrations of some aromas including: volatile phenols, such as guaiacol, 4-EG, phenol, syringol; some phenolic aldehydes, such as 2-(4-hydroxy-3-methoxyphenyl) acetaldehyde, acetovanillone, 1-(4-hydroxy-3-methoxyphenyl)-2-propanone, butyrovanillone, 2-(4-hydroxy3,5-dimethoxyphenyl) acetaldehyde, acetosyringone, 1-(4-hydroxy-3,5-dimethoxyphenyl)2-propanone, propiosyringone, benzaldehyde and the minor ones of 2-furanyl-1-ethanone, methyl vanillyl ether, syringaldehyde, coniferaldehyde and sinapaldehyde [64]. Figure 1b shows how this wood after seasoning stands out for its content of furanic compounds $(21.3 \mu \mathrm{g} / \mathrm{g})$.

During toasting, at $160-170{ }^{\circ} \mathrm{C}$ for $35 \mathrm{~min}$, the cis and trans lactone contents decreased by about $80 \%$ and $40 \%$, respectively, whereas in traditional woods they increased during toasting. Therefore, the toasted wood of $Q$. faginea is probably a lactone-poor wood among the Quercus woods (Table 4 and Figure 1c). The concentrations of the other volatile compounds studied after toasting were between those found in Q. petraea and Q. alba, with some exceptions, such as the higher content of 4-methylsyringol, benzaldehyde, benzothiazole, 2-phenoethanol and ethyl vanillyl ether and the lower content of isomaltol, 1-(4-hydroxy-3-methoxyphenyl)-2-butanone, butyrovanillone and methyl vanillyl ether. Furthermore, as shown in Figure 1c, this wood showed a low content of furanic compounds, the Quercus wood having the lowest content $(185 \mu \mathrm{g} / \mathrm{g})$ and the one with the highest average content of phenolic aldehydes/phenyl ketones $(521.97 \mu \mathrm{g} / \mathrm{g})$. 
Table 4. Volatile compounds expressed as $\mu \mathrm{g} / \mathrm{g}$ of wood found in extracts of toasted woods of different botanical origins.

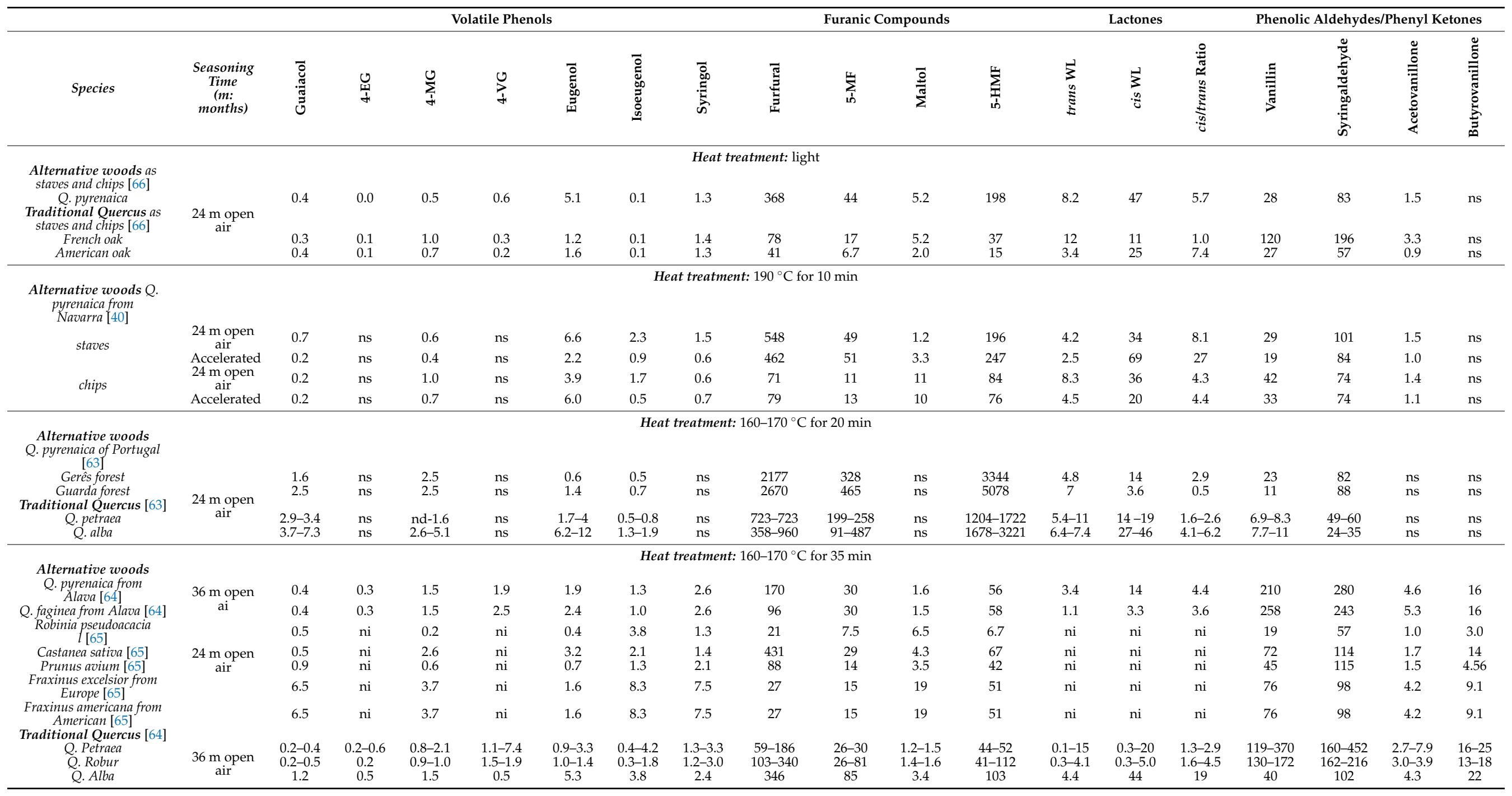


Table 4. Cont.

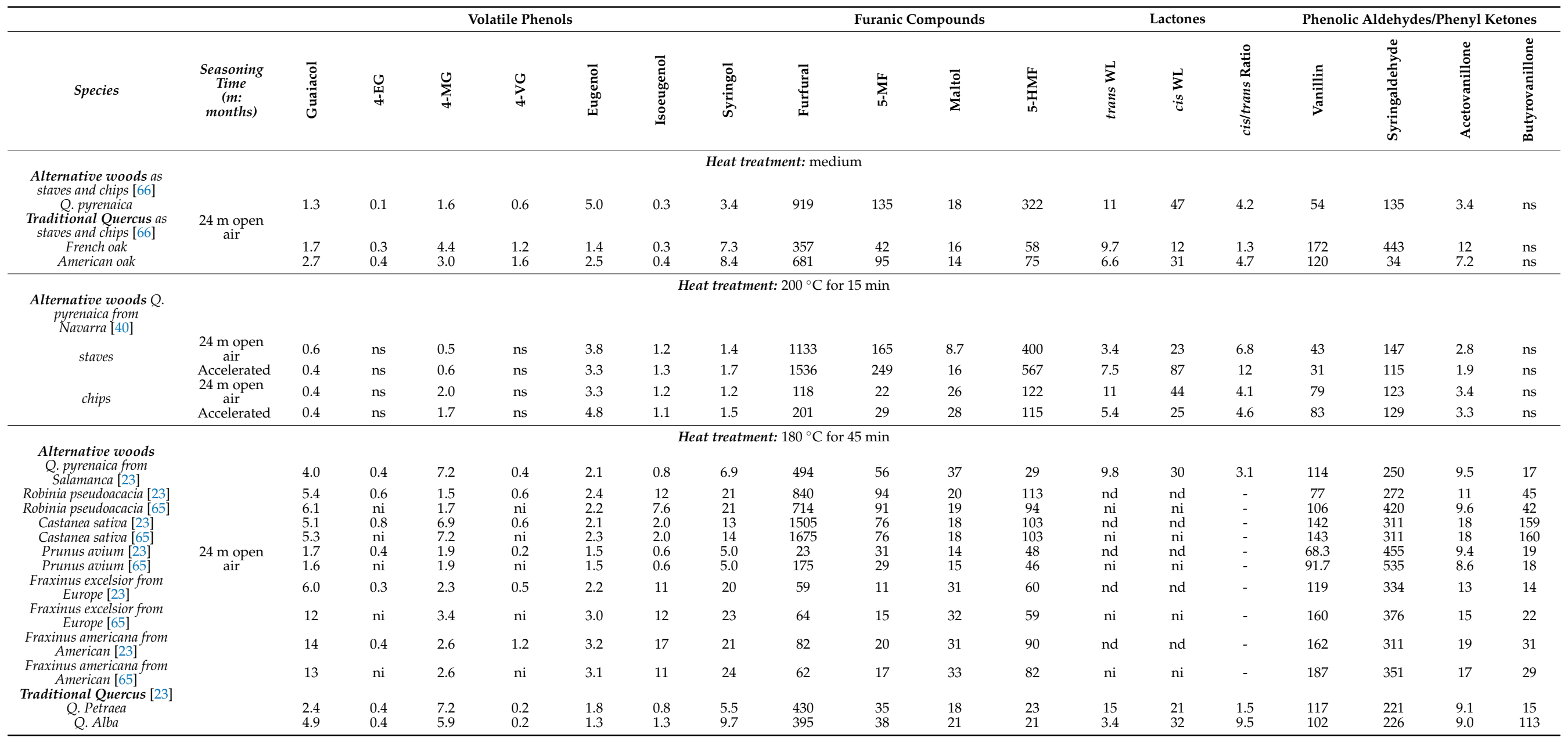


Table 4. Cont.

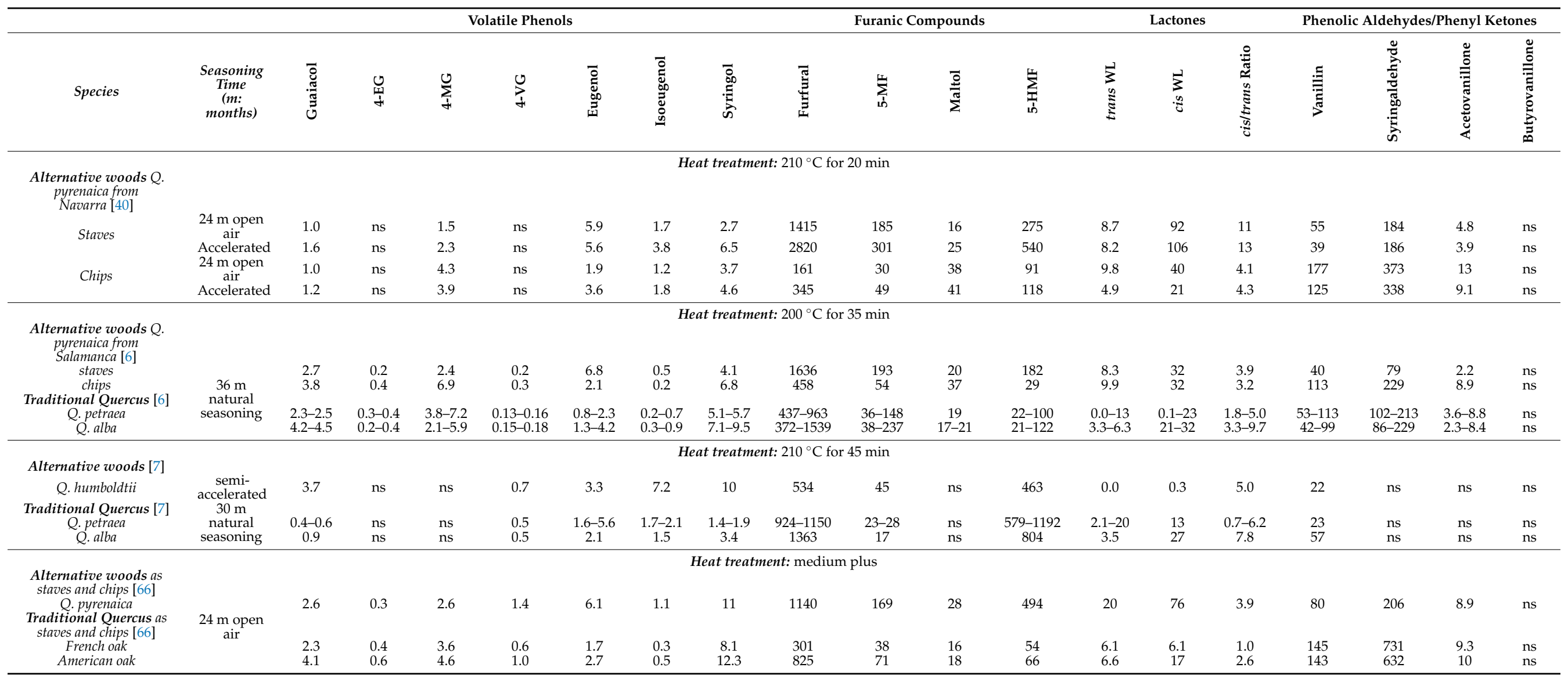


Table 4. Cont.

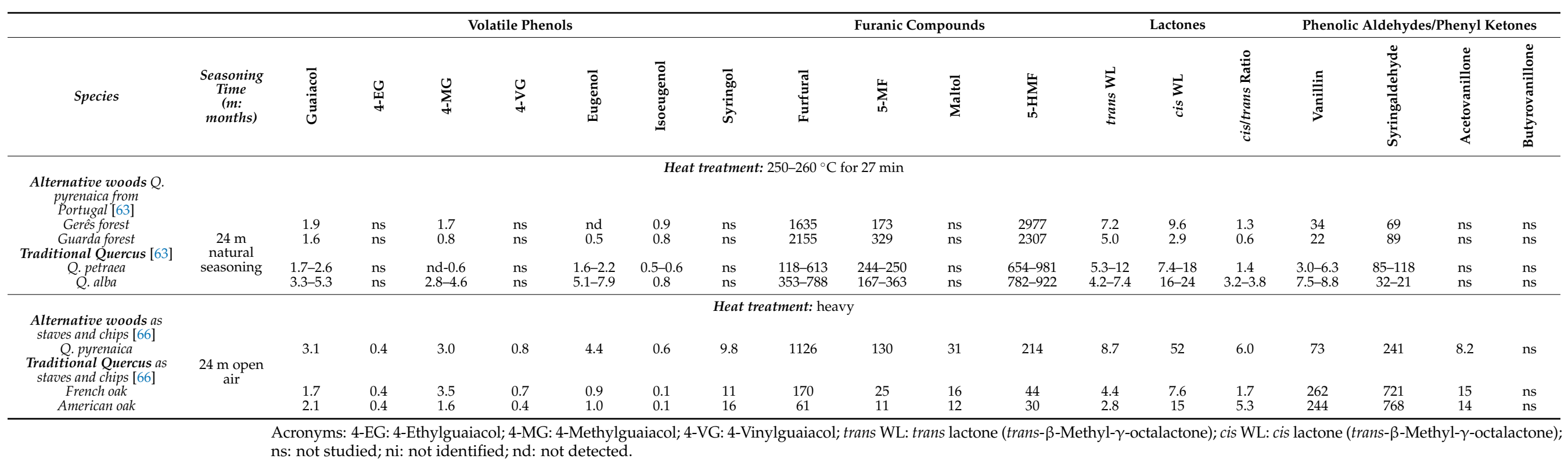




\section{Quercus humboldtii Bonpl}

This wood seems to be of great interest in ageing, especially for rums. It has only been studied after toasting, so more studies would be necessary to know how drying and toasting really affect the volatile composition of this wood. The toasted wood of $Q$. humboldtii showed significant contents of 5-MF $(386 \mu \mathrm{g} / \mathrm{g})$, guaiacol $(25.5 \mu \mathrm{g} / \mathrm{g}), 4-\mathrm{VG}$ $(13.6 \mu \mathrm{g} / \mathrm{g})$, cis isoeugenol $(34.3 \mu \mathrm{g} / \mathrm{g})$ and syringol $(58 \mu \mathrm{g} / \mathrm{g})$, higher than those found in the wood of traditional species. Of these compounds, 4 -VG showed the least difference between this wood and the traditional ones. However, 5-MF found in Q. humboldtii wood had twice the concentration found in traditional woods, cis isoeugenol and syringol three times and guaiacol four times. Therefore, the average volatile phenols content of this wood was higher than that of the traditional woods (Figure 1d; $377 \mu \mathrm{g} / \mathrm{g}$ versus $209 \mu \mathrm{g} / \mathrm{g}$ for $Q$. petraea and $291 \mu \mathrm{g} / \mathrm{g}$ for Q. alba). However, it is a wood poor in furfural, 5-HMF, trans and cis lactones. Due to the very low concentrations of lactones found in this wood, it could be said that this wood lacks the typical coconut aroma that can be transmitted to wines by these molecules (Figure 1d), especially since the cis isomer $(0.3 \mu \mathrm{g} / \mathrm{g})$ is 42 and 95 times lower than traditional woods $(12.7-27.1 \mu \mathrm{g} / \mathrm{g})$.

\section{Robinia pseudoacacia (Acacia)}

The volatile composition of acacia wood has been studied both when dried and toasted, for cooperage purposes and its use with alcoholic beverages, especially wines and vinegars. Flamini et al., 2007 [71] found the Italian seasoned wood interesting, especially for its content of benzoic aldehydes, such as hydroxybenzaldehyde, anisaldehyde, vanillin and syringaldehyde. The last two, known for their contribution with vanilla notes, were of the order of those found by other authors [23,65]. However, when comparing the concentrations of vanillin and syringaldehyde found in Quercus [23], it was found that the seasoned acacia wood had similar or even lower contents. Furthermore, Table 3 shows that seasoned acacia wood is poor in eugenol, furanic compounds, especially furfural, and phenyl ketones. Therefore, Figure $1 \mathrm{~b}$ shows how this wood stands out for its low content of furanic compounds and phenolic aldehydes/phenyl ketones next to cherry and the absence of lactones as all non-Quercus woods. After light toasting, this wood still shows low amounts of these compounds compared to Quercus woods (Table 3 and Figure 1c). However, after toasting at $180{ }^{\circ} \mathrm{C}$ for $45 \mathrm{~min}$, it showed interesting contents of guaiacol, eugenol, isoeugenol, syringol, furanic compounds, especially furfural, syringaldehyde and acetovanillone (Table 3). Thus, Figure $1 \mathrm{~d}$ shows that this wood has a higher content of volatile phenols than Quercus, $607 \mu \mathrm{g} / \mathrm{g}$ compared to $290-209 \mu \mathrm{g} / \mathrm{g}$, of the order of the furanic compounds content of traditional woods ( 993 to about $1100 \mu \mathrm{g} / \mathrm{g}$ ), and phenolic aldehydes/phenyl ketones higher than Quercus woods and of the order of non-Quercus woods.

In seasoned and toasted acacia wood, the compounds not found in Quercus were: catechol, 3-methylcatechol, cyclone, 3,4-dimethoxyphenol and 2,4-dihydroxybenzaldehyde [23]. The last two compounds were only found in acacia wood, presenting contents of 1.24-1.83 and $14.90-16.7 \mu \mathrm{g} / \mathrm{g}$, respectively, in seasoned wood and $0.72-1.17$ and $89.3-91.7 \mu \mathrm{g} / \mathrm{g}$ in toasted wood, so it could be said that they are characteristic of this wood [23,65]. In addition, resorcinol, a compound never detected in wood, was detected in acacia [65]. However, acacia wood both after seasoning and toasting does not possess certain volatile compounds found in Quercus [23] such as methyl benzoate, methyl homovanillate, methyl vanillate, methyl syringate, isobutyrovanillone, trans and cis lactones, these lactones being of special interest for providing aromatic notes of coconut to the wines. As in other non-Quercus wood (cherry, chestnut and ash), the contents of most of these compounds increased during toasting, as well as those of phenyl alcohols, while in Quercus wood they decreased or did not change [23]. However, other compounds decreased in concentration during toasting in acacia wood such as: 3,4-dimethoxyphenol, 3,4,4-trimethoxyphenol, acetic acid, hexanoic acid, hexadecanoic acid and 1-hexanal [23,65]. 


\section{Castanea sativa (Chestnut)}

This wood has been widely used for oenological purposes in the Mediterranean area in the past due to its wide availability and low cost. Moreover, it is the only non-Quercus species accepted for use by the OIV. This wood, after being seasoned, is distinguished by its phenolic aldehydes/phenyl ketones content (Figure 1b) and has the same or even higher contents of volatile phenols and furanic compounds than traditional woods. Like the other non-Quercus woods, they lack lactones. The compounds generally increase during toasting; the higher the toasting, the higher the content. These increases during toasting are very significant in acacia, chestnut and ash wood, especially in chestnut wood, which is the richest as a whole, in compounds derived from lignin, lipids and carbohydrates [23]. Chestnut wood showed higher contents than Quercus wood, especially when toasted at $180{ }^{\circ} \mathrm{C}$ for $45 \mathrm{~min}$, in compounds such as volatile phenols (guaiacol, 4-VG, eugenol, isoeugenol and syringol), furanic compounds (furfural, 5-MF, 5-HMF, 5-acetoxymethyl-2-furfural, 1-methoxy-2-ethoxyethyl-1-furan) and phenolic aldehydes/phenyl ketones (vanillin, syringaldehyde, acetovanillone, butyrovanillone, propiovanillone, propiosyringone, butyrosyringone, isoacetovanillone, isopropiovanillone, isoacetosyringone, isopropiosyringone, methyl homovanillate and acetophenone) [23]. All this indicates that it is a very rich wood aromatically after toasting, especially after medium toasting (Figure 1c). This figure shows how this wood is more aromatic than traditional and other woods in furanic compounds and phenolic aldehydes/phenyl ketones, and the content of volatile phenols is higher than Quercus, but it is not the richest wood in these compounds. However, coconut notes would not be contributed or would play an insignificant role with these woods, since in their composition, according to some authors, neither of the two lactone isomers were found [23], and according to others, they were found in low concentrations $(<0.7 \mu \mathrm{g} / \mathrm{g})[65]$.

\section{Prunus avium (Cherry)}

The composition of cherry was studied after 24 months of seasoning and after light and medium toasting $[23,65]$. In cherry wood, p-anisaldehyde, p-anisylacetone, p-anisyl alcohol, 7,8-dihydro-3-oxo- $\alpha$-ionol, 7,8 -dihydro-4-oxo- $\beta$-ionol and benzyl salicylate, not found in any other woods, were found, so these compounds could be considered characteristic of cherry wood. Of these compounds, p-anisaldehyde and benzyl salicylate were the ones found in the highest concentrations. The p-anisaldehyde increased significantly during toasting from $0.18-0.33 \mu \mathrm{g} / \mathrm{g}$ in dry wood to $0.45 \mu \mathrm{g} / \mathrm{g}$ after light toasting to $4.36-4.41 \mu \mathrm{g} / \mathrm{g}$ after medium toasting, while benzyl salicylate decreased during this process from $4.46-7.67 \mu \mathrm{g} / \mathrm{g}$ in dry wood to $0.61-0.68 \mu \mathrm{g} / \mathrm{g}$ in wood after medium toasting. In seasoned cherry wood, the three most abundant compounds were 3,4,5-trimethoxyphenol, methyl syringate, and benzoic acid and in toasted wood they are syringaldehyde and sinapaldehyde.

Cherry wood after seasoning and toasting was the poorest in vanillin, followed by acacia, with almost less than half the concentration of Quercus wood. However, especially after medium toasting the syringaldehyde content of cherry wood was higher than that of traditional woods $455-535 \mu \mathrm{g} / \mathrm{g}$ compared to $221-226 \mu \mathrm{g} / \mathrm{g}$, so the phenolic aldehy$\mathrm{des} /$ phenyl ketones content was high (Figure 1d). The furfural content in seasoned wood was very low and the increase during toasting was very small compared to that of the other woods, which makes toasted cherry wood very poor in this compound, and generally in furanic compounds (Figure $1 \mathrm{~b}-\mathrm{d}$ ). In general, the volatile phenols presented in Tables 3 and 4 show a behaviour during toasting similar to Quercus, presenting contents similar to traditional woods, although the wood after medium toasting presents lower contents of guaiacol, 4-MG and syringol.

\section{Fraxinus excelsior (European ash) and Fraxinus americana (American ash)}

Ash wood did not show any unique volatile compounds, as all compounds present in ash wood were detected in at least one other wood, be it acacia, chestnut, cherry or Quercus. However, quantitative differences can clearly be used to identify toasted 
ash wood, with tyrosol being the most interesting, since, although in seasoned wood it is found in this wood and in oak wood, after toasting it was only found in ash wood and in high concentrations, 24.6 and $26.4 \mu \mathrm{g} / \mathrm{g}$ in the European and American species, respectively. Furthermore, this wood is quantitatively different and with higher contents in certain volatile compounds than all the woods compared (acacia, cherry, acacia, Q. pyrenaica, Q. petraea and $Q$. alba), especially after toasting, including: catechol, 3-methylcatechol, homovanillyl alcohol, coniferaldehyde, 2-phenoxyethanol, 1-hydroxy-2butanone, 1-acetyloxy-2-butanone, $\gamma$-butyrolactone, solerone, 3,5-dimethylcyclotene, 4,5dimethyl-2-cyclohexen-1-one, 2-furanmethanol, 3-ethylcyclotene, $\alpha$-methylcrotonolactone, solerone and 3-hydroxybenzaldehyde. Focusing on volatile compounds sought after by consumers, it was observed that ash wood also had high contents of guaiacol, isoeugenol, syringol and maltol, as well as vanillin, syringaldehyde and acetovanillone, when subjected to medium toasting (Table 4). Therefore, after light and medium toasting it is a wood with more volatile phenols (Figure 1c,d) and after medium toasting more phenolic aldehydes/phenyl ketones than Quercus (Figure 1d). However, the wood is rather low in furfural (Table 4) with very low contents of furanic compounds after all cooperage treatments (Figure $1 \mathrm{~b}-\mathrm{d}$ ). There are compounds that are not detected in ash wood but are in traditional woods, such as trans and cis lactones, which are of great interest. American toasted ash wood appears to be more aromatic than European ash wood in most of the compounds $[23,65]$, as well as in the compounds represented in Table 4.

\section{Morus alba (mulberry)}

The volatile composition of this wood has been little studied, and no studies were found that focused on its toasting, a very important process in the formation of aromas. After seasoning, mulberry wood seemed to be the poorest in volatile benzene compounds, and certain compounds of great aromatic interest, such as eugenol, methoxyeugenol, vinylguaiacol and syringol, were not detected [71]. The concentrations of vanillin and syringaldehyde found were very low; however, it presented important extraction percentages, especially of vanillin, which differed considerably from those of oak wood, probably due to the different porosity of the wood [71].

\section{Influence of Ageing with Alternative Woods on the Volatile Composition of Wine: Comparison with Traditional Oak Woods}

In this section, we have compiled the existing data from the scientific literature on the effects of the use of different types of wood, traditional and alternative, on the volatile composition of wines. Data are included both from studies carried out with barrels (Table 5) and those carried out with chips and staves (Table 6).

\subsection{Ageing in Barrels with Traditional and Alternative Woods}

The compiled bibliography studies the ageing of wines from 4 months (short ageing) to 21 months (long ageing) in alternative barrels and compares them with traditional barrels. The most common wine ageing was with medium-long wood contact time (between 9 and 21 months) (Table 5). It is expected that, as the ageing time increases, the variety and the content of volatile compounds in the wine increase. However, this will also depend on the factors mentioned above (degree of toasting, toasting temperature, type of wine, etc.). 
Table 5. Volatile compounds in wines after ageing in barrels from woods of different botanical origins expressed as $\mu \mathrm{g} / \mathrm{L}$.

\begin{tabular}{|c|c|c|c|c|c|c|c|c|c|c|c|c|c|c|c|c|c|c|c|c|c|}
\hline \multirow[b]{2}{*}{ 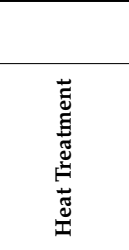 } & \multirow[b]{2}{*}{ 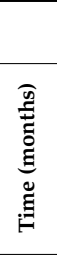 } & \multirow[b]{2}{*}{ 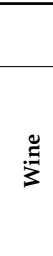 } & \multirow[b]{2}{*}{ Species } & \multirow[b]{2}{*}{ 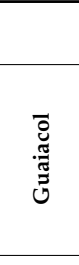 } & \multicolumn{5}{|c|}{ Volatile Phenols } & \multirow[b]{2}{*}{ 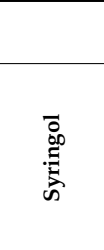 } & \multicolumn{4}{|c|}{ Furanic Compounds } & \multicolumn{3}{|c|}{ Lactones } & \multicolumn{4}{|c|}{$\begin{array}{l}\text { Phenolic Aldehydes/ } \\
\text { Phenyl Ketones }\end{array}$} \\
\hline & & & & & 号 & $\sum_{j}^{0}$ & 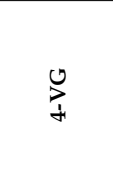 & 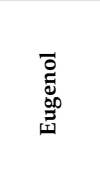 & 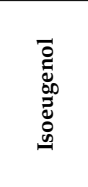 & & 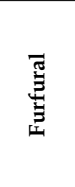 & $\sum_{i=1}^{1}$ & $\frac{\overline{\mathrm{g}}}{\sum_{\mathrm{J}}^{\mathrm{s}}}$ & 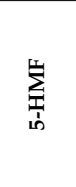 & 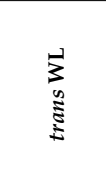 & $\begin{array}{l}3 \\
0 \\
0 \\
0\end{array}$ & 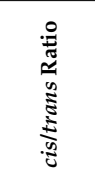 & 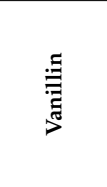 & 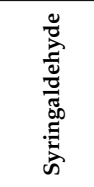 & 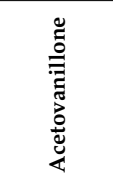 & 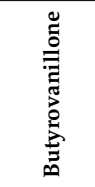 \\
\hline $\begin{array}{l}100^{\circ} \mathrm{C} \text { for } \\
60 \mathrm{~min}\end{array}$ & 4 & 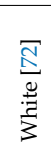 & $\begin{array}{l}\text { Alternative woods } \\
\text { Robinia pseudoacacia }\end{array}$ & 0.8 & 0.7 & 0.3 & 3.0 & 0.6 & ns & 1.5 & 9.2 & 0.1 & ns & 0.8 & ns & ns & ns & 1.2 & 1.0 & 35 & ns \\
\hline nontoasted & 6 & 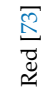 & Castanea sativa & 35 & 134 & 24.5 & 41 & 139 & 63 & 285 & 9.7 & 64 & 2.4 & 3.3 & ns & ns & ns & 157 & 108 & 136 & 57 \\
\hline $\begin{array}{l}160-170{ }^{\circ} \mathrm{C} \\
\text { for } \\
45-50 \mathrm{~min}\end{array}$ & 6 & 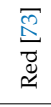 & Castanea sativa & 35 & 124 & 30 & 40 & 162 & 92 & 242 & 15.7 & 184 & 3.3 & 6.2 & ns & ns & ns & 241 & 253 & 155 & 58 \\
\hline $\begin{array}{l}{ }^{\circ} \mathrm{C} \text { offire } \\
\text { for } 40 \mathrm{~min}\end{array}$ & 9 & 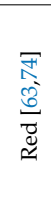 & $\begin{array}{l}\text { Alternative woods } \\
\text { Robinia pseudoacacia } \\
\text { Castanea sativa } \\
\text { Prunus avium } \\
\text { Morus alba } \\
\text { Traditional } \\
\text { Quercus } \\
\text { Q. petraea }\end{array}$ & $\begin{array}{l}\text { ns } \\
\text { ns } \\
\text { ns } \\
\text { ns } \\
\\
\text { ns }\end{array}$ & $\begin{array}{l}3250 \\
1840 \\
2790 \\
1840 \\
\\
\\
2900\end{array}$ & $\begin{array}{l}\text { ns } \\
\text { ns } \\
\text { ns } \\
\text { ns } \\
\text { ns }\end{array}$ & $\begin{array}{l}\text { ns } \\
\text { ns } \\
\text { ns } \\
\text { ns } \\
\text { ns }\end{array}$ & $\begin{array}{l}21 \\
26 \\
7 \\
6 \\
\\
\\
18\end{array}$ & $\begin{array}{l}\text { ns } \\
\text { ns } \\
\text { ns } \\
\text { ns } \\
\text { ns }\end{array}$ & $\begin{array}{l}\text { ns } \\
\text { ns } \\
\text { ns } \\
\text { ns } \\
\text { ns }\end{array}$ & $\begin{array}{l}30 \\
70 \\
\text { nd } \\
\text { nq } \\
\\
600\end{array}$ & $\begin{array}{l}30 \\
40 \\
\text { nd } \\
\text { nq } \\
\\
\\
320\end{array}$ & $\begin{array}{l}\text { ns } \\
\text { ns } \\
\text { ns } \\
\text { ns } \\
\\
\text { ns }\end{array}$ & $\begin{array}{l}\text { ns } \\
\text { ns } \\
\text { ns } \\
\text { ns } \\
\text { ns }\end{array}$ & $\begin{array}{l}\text { ns } \\
\text { ns } \\
\text { ns } \\
\text { ns } \\
\text { ns }\end{array}$ & $\begin{array}{l}\text { ns } \\
\text { ns } \\
\text { ns } \\
\text { ns } \\
\text { ns }\end{array}$ & $\begin{array}{l}\text { ns } \\
\text { ns } \\
\text { ns } \\
\text { ns } \\
\text { ns }\end{array}$ & $\begin{array}{l}310 \\
430 \\
120 \\
80 \\
\\
360\end{array}$ & $\begin{array}{l}\text { ns } \\
\text { ns } \\
\text { ns } \\
\text { ns } \\
\text { ns }\end{array}$ & $\begin{array}{l}\text { ns } \\
\text { ns } \\
\text { ns } \\
\text { ns } \\
\text { ns }\end{array}$ & $\begin{array}{l}\text { ns } \\
\text { ns } \\
\text { ns } \\
\text { ns } \\
\text { ns }\end{array}$ \\
\hline \multirow[t]{3}{*}{$\begin{array}{l}165{ }^{\circ} \mathrm{C} \text { for } \\
35 \mathrm{~min}\end{array}$} & \multirow[t]{3}{*}{12} & \multirow[t]{3}{*}{ 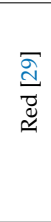 } & $\begin{array}{l}\text { Alternative woods } \\
\text { Q. pyrenaica } \\
\text { Traditional } \\
\text { Quercus }\end{array}$ & $31-76$ & $5.3-45$ & $17-37$ & 93-315 & $81-116$ & $42-111$ & $241-736$ & $\begin{array}{l}134- \\
3575\end{array}$ & $94-2477$ & $111-282$ & $\begin{array}{l}757- \\
3533\end{array}$ & $184-231$ & $\begin{array}{l}718- \\
1096\end{array}$ & $3.9-5.1$ & $342-574$ & $\begin{array}{l}553- \\
1748\end{array}$ & $121-223$ & $\begin{array}{l}897- \\
1164\end{array}$ \\
\hline & & & Q.petraea & $25-40$ & 5.6-105 & $17-48$ & $68-409$ & $23-44$ & $27-120$ & $194-631$ & $\begin{array}{l}110- \\
1543\end{array}$ & $51-869$ & $92-163$ & $\begin{array}{l}986- \\
1611\end{array}$ & $125-735$ & $\begin{array}{l}396- \\
1174\end{array}$ & $1.6-3.2$ & $357-854$ & $\begin{array}{l}735- \\
2244\end{array}$ & $102-309$ & $417-981$ \\
\hline & & & Q. alba & $27-55$ & $5.0-77$ & $16-66$ & $109-269$ & $50-63$ & $30-82$ & $185-724$ & $\begin{array}{l}187- \\
5256 \\
\end{array}$ & $42-1543$ & 159-197 & $\begin{array}{l}713- \\
2723 \\
\end{array}$ & $141-236$ & $\begin{array}{l}992- \\
1313 \\
\end{array}$ & $5.6-7.0$ & $437-806$ & $\begin{array}{l}1378- \\
2274 \\
\end{array}$ & $128-286$ & $488-995$ \\
\hline \multirow[t]{2}{*}{$\begin{array}{l}185^{\circ} \mathrm{C} \text { for } \\
45 \mathrm{~min}\end{array}$} & \multirow[t]{2}{*}{12} & \multirow[t]{2}{*}{ 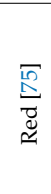 } & $\begin{array}{l}\text { Alternative woods } \\
\text { Robinia pseudoacacia } \\
\text { Castanea sativa } \\
\text { Prunus avium } \\
\text { Fraxinus excelsior } \\
\text { Traditional } \\
\text { Ouercus }\end{array}$ & $\begin{array}{l}60 \\
59 \\
43 \\
75\end{array}$ & $\begin{array}{l}20 \\
49 \\
73 \\
92\end{array}$ & $\begin{array}{l}14 \\
52 \\
25 \\
35\end{array}$ & $\begin{array}{l}26 \\
24 \\
23 \\
31\end{array}$ & $\begin{array}{l}19 \\
118 \\
11 \\
13\end{array}$ & $\begin{array}{l}54 \\
36 \\
19 \\
37\end{array}$ & $\begin{array}{l}217 \\
153 \\
169 \\
198\end{array}$ & $\begin{array}{l}238 \\
509 \\
101 \\
66\end{array}$ & $\begin{array}{l}450 \\
241 \\
32 \\
58\end{array}$ & $\begin{array}{l}300 \\
125 \\
133 \\
354\end{array}$ & $\begin{array}{l}248 \\
689 \\
145 \\
339\end{array}$ & $\begin{array}{l}\text { nd } \\
21 \\
\text { nd } \\
\text { nd }\end{array}$ & $\begin{array}{l}\text { nd } \\
31 \\
\text { nd } \\
\text { nd }\end{array}$ & $\begin{array}{l}1.5 \\
\text { nd } \\
\text { nd }\end{array}$ & $\begin{array}{l}233 \\
456 \\
304 \\
696\end{array}$ & $\begin{array}{l}768 \\
1189 \\
1877 \\
1090\end{array}$ & $\begin{array}{l}61 \\
92 \\
75 \\
111\end{array}$ & $\begin{array}{l}105 \\
226 \\
132 \\
150\end{array}$ \\
\hline & & & Q. petraea & 44 & 24 & 32 & 21 & 101 & 53 & 178 & 40 & 842 & 142 & 703 & 99 & 577 & & 408 & 1305 & 62 & 193 \\
\hline
\end{tabular}


Table 5. Cont.

\begin{tabular}{|c|c|c|c|c|c|c|c|c|c|c|c|c|c|c|c|c|c|c|c|c|c|}
\hline \multirow[b]{2}{*}{ 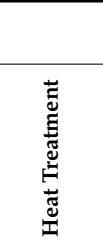 } & \multirow[b]{2}{*}{ 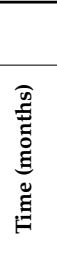 } & \multirow[b]{2}{*}{$\underset{3}{\xi}$} & \multirow[b]{2}{*}{ Species } & \multicolumn{7}{|c|}{ Volatile Phenols } & \multicolumn{4}{|c|}{ Furanic Compounds } & \multicolumn{3}{|c|}{ Lactones } & \multicolumn{4}{|c|}{$\begin{array}{l}\text { Phenolic Aldehydes/ } \\
\text { Phenyl Ketones }\end{array}$} \\
\hline & & & & 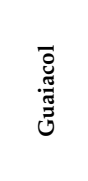 & 华 & $\sum_{j}^{0}$ & 岁 & 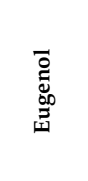 & 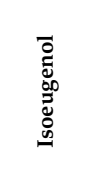 & 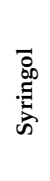 & 莺 & $\sum_{i=1}^{\infty}$ & $\frac{\overline{5}}{\frac{\bar{\pi}}{\pi}}$ & 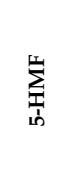 & $\begin{array}{l}\overrightarrow{3} \\
\text { 离 } \\
\underline{\Sigma}\end{array}$ & $\begin{array}{l}3 \\
8 \\
8\end{array}$ & 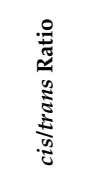 & 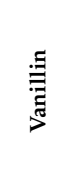 & 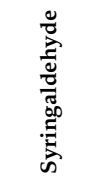 & 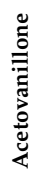 & 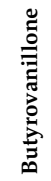 \\
\hline \multirow[t]{2}{*}{ Medium } & \multirow[t]{2}{*}{12} & \multirow[t]{2}{*}{ 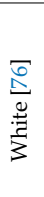 } & $\begin{array}{l}\text { Alternative woods } \\
\text { Robinia pseudoacacia } \\
\text { from Medjimurje } \\
\text { from Istria } \\
\text { Traditional } \\
\text { Quercus }\end{array}$ & $\begin{array}{l}31 \\
2.7\end{array}$ & $\begin{array}{l}2.6 \\
0.7\end{array}$ & $\begin{array}{l}\text { ns } \\
\text { ns }\end{array}$ & $\begin{array}{l}\text { ns } \\
\text { ns }\end{array}$ & $\begin{array}{l}8.0 \\
2.5\end{array}$ & $\begin{array}{l}33 \\
8.6\end{array}$ & $\begin{array}{l}\text { ns } \\
\text { ns }\end{array}$ & $\begin{array}{c}1236 \\
83\end{array}$ & $\begin{array}{l}251 \\
4.3\end{array}$ & $\begin{array}{l}\text { ns } \\
\text { ns }\end{array}$ & $\begin{array}{l}\text { ns } \\
\text { ns }\end{array}$ & $\begin{array}{l}0.3 \\
0.2\end{array}$ & $\begin{array}{l}0.5 \\
0.4\end{array}$ & & $\begin{array}{l}0.03 \\
0.02\end{array}$ & $\begin{array}{l}0.3 \\
0.3\end{array}$ & $\begin{array}{l}\text { ns } \\
\text { ns }\end{array}$ & $\begin{array}{l}\text { ns } \\
\text { ns }\end{array}$ \\
\hline & & & Q. petraea & $4.9-9.2$ & $0.6-1.3$ & ns & ns & $4.4-6.6$ & $3.6-7.9$ & ns & $\begin{array}{l}740- \\
1796 \\
\end{array}$ & $93-173$ & ns & ns & $0.5-39$ & $11-43$ & & $\begin{array}{l}0.02- \\
0.05\end{array}$ & 0.1 & ns & ns \\
\hline \multirow[t]{3}{*}{ Medium } & \multirow[t]{3}{*}{21} & \multirow{3}{*}{ 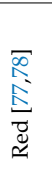 } & $\begin{array}{c}\text { Alternative woods } \\
\text { Q. pyrenaica } \\
\text { Q. faginea } \\
\text { Traditional } \\
\text { Quercus }\end{array}$ & $\begin{array}{l}20 \\
22\end{array}$ & $\begin{array}{l}\text { ns } \\
\text { ns }\end{array}$ & $\begin{array}{l}\text { ns } \\
\text { ns }\end{array}$ & $\begin{array}{l}\text { ns } \\
\text { ns }\end{array}$ & $\begin{array}{l}42 \\
41\end{array}$ & $\begin{array}{l}\text { ns } \\
\text { ns }\end{array}$ & $\begin{array}{l}\text { ns } \\
\text { ns }\end{array}$ & $\begin{array}{l}49 \\
44\end{array}$ & $\begin{array}{l}15 \\
13\end{array}$ & $\begin{array}{l}78 \\
72\end{array}$ & $\begin{array}{l}49 \\
26\end{array}$ & $\begin{array}{l}67 \\
103\end{array}$ & $\begin{array}{l}229 \\
352\end{array}$ & $\begin{array}{l}3.4 \\
3.4\end{array}$ & $\begin{array}{l}78 \\
74\end{array}$ & $\begin{array}{l}75 \\
64\end{array}$ & $\begin{array}{l}\text { ns } \\
\text { ns }\end{array}$ & $\begin{array}{l}\text { ns } \\
\text { ns }\end{array}$ \\
\hline & & & Q. petraea & $24-27$ & ns & ns & ns & $35-48$ & ns & ns & $90-93$ & $26-28$ & 118-135 & $49-75$ & $28-150$ & $66-347$ & $2.3-2.4$ & $80-91$ & $135-150$ & ns & ns \\
\hline & & & $\begin{array}{l}\text { Q. robur } \\
\text { Q. alba }\end{array}$ & $\begin{array}{c}23-28 \\
43\end{array}$ & $\begin{array}{l}\text { ns } \\
\text { ns }\end{array}$ & $\begin{array}{l}\text { ns } \\
\text { ns }\end{array}$ & $\begin{array}{l}\text { ns } \\
\text { ns }\end{array}$ & $\begin{array}{c}37-54 \\
89\end{array}$ & $\begin{array}{l}\text { ns } \\
\text { ns }\end{array}$ & $\begin{array}{l}\text { ns } \\
\text { ns }\end{array}$ & $\begin{array}{l}60-67 \\
124\end{array}$ & $\begin{array}{l}13-26 \\
96\end{array}$ & $\begin{array}{c}98-117 \\
172\end{array}$ & $\begin{array}{l}20-56 \\
85\end{array}$ & $\begin{array}{c}101-185 \\
92\end{array}$ & $\begin{array}{c}331-407 \\
788\end{array}$ & $\begin{array}{c}1.8-4.1 \\
8.8\end{array}$ & $\begin{array}{l}59-84 \\
145\end{array}$ & $\begin{array}{c}72-136 \\
168\end{array}$ & $\begin{array}{l}\text { ns } \\
\text { ns }\end{array}$ & $\begin{array}{l}\text { ns } \\
\text { ns }\end{array}$ \\
\hline
\end{tabular}

Barrel volume = $225 \mathrm{~L}$. Acronyms: 4-EG: 4-Ethylguaiacol; 4-MG: 4-Methylguaiacol; 4-VG: 4-Vinylguaiacol; trans WL: trans lactone (trans- $\beta$-Methyl- $\gamma$-octalactone); cis WL: cis lactone (trans- $\beta$-Methyl- $\gamma$-octalactone); ns: not studied; nd: not detected. 
Table 6. Volatile compounds in wines after alternative ageing with woods of different botanical origin expressed as $\mu \mathrm{g} / \mathrm{L}$

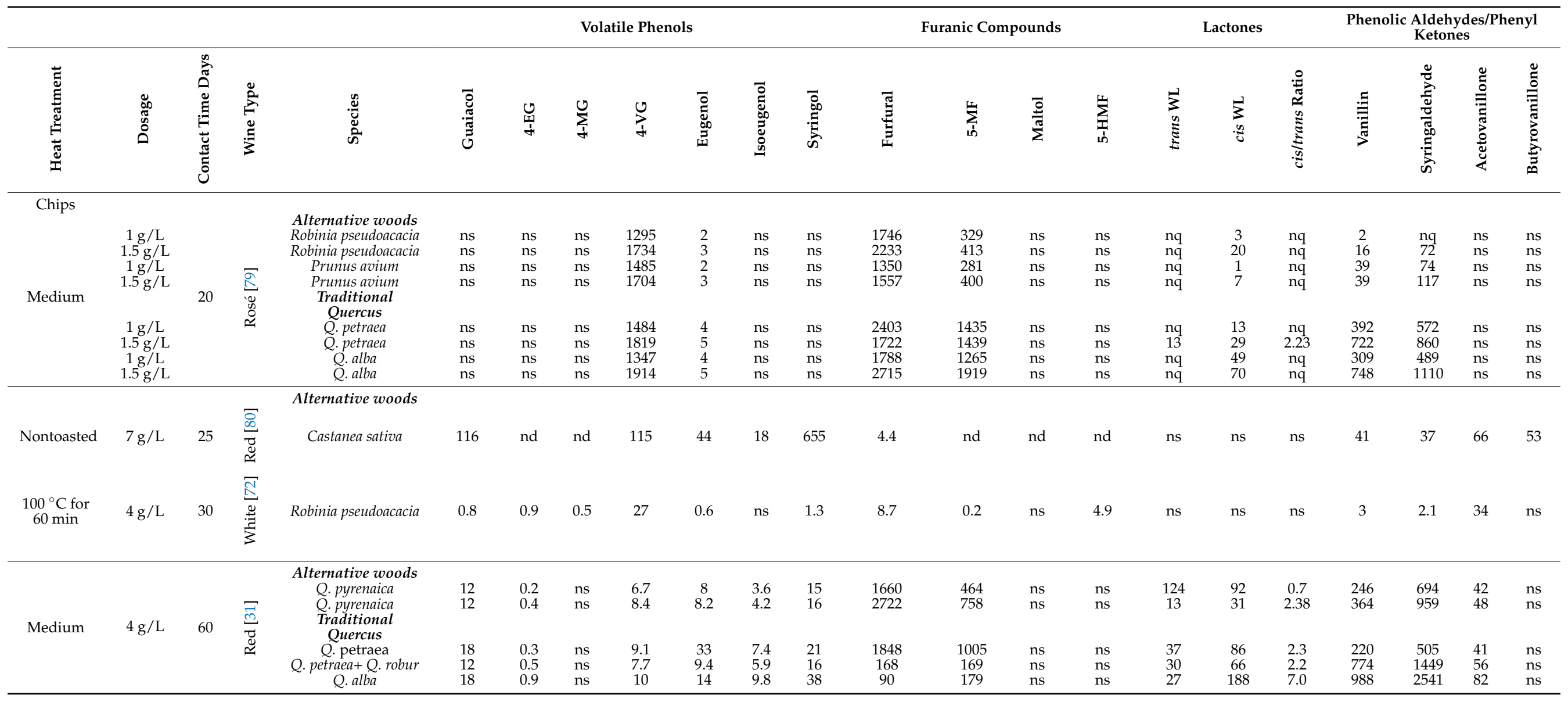


Table 6. Cont.

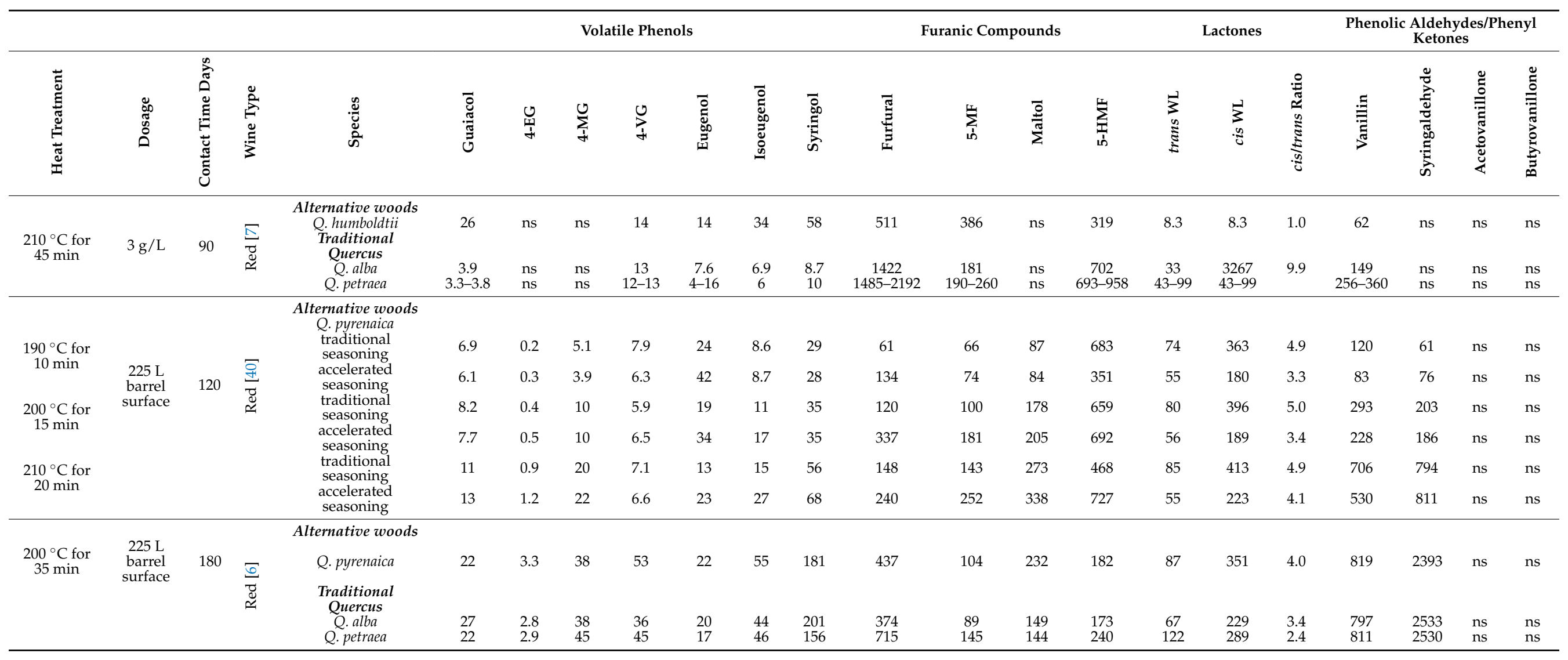


Table 6. Cont.

\begin{tabular}{|c|c|c|c|c|c|c|c|c|c|c|c|c|c|c|c|c|c|c|c|c|c|c|}
\hline \multirow[b]{2}{*}{ 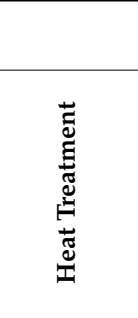 } & \multirow[b]{2}{*}{ 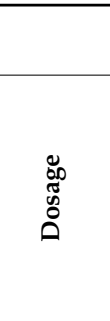 } & \multirow[b]{2}{*}{ 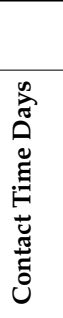 } & \multirow[b]{2}{*}{ 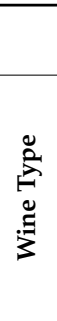 } & \multirow[b]{2}{*}{$\begin{array}{l}\mathscr{D}_{\tilde{J}}^{\infty} \\
\text { के }\end{array}$} & \multicolumn{7}{|c|}{ Volatile Phenols } & \multicolumn{4}{|c|}{ Furanic Compounds } & \multicolumn{3}{|c|}{ Lactones } & \multicolumn{4}{|c|}{$\begin{array}{l}\text { Phenolic Aldehydes/Phenyl } \\
\text { Ketones }\end{array}$} \\
\hline & & & & & 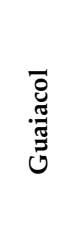 & $\underset{\substack{9 \\
4}}{0}$ & $\sum_{i}^{U}$ & $\begin{array}{l}0 \\
+ \\
+\end{array}$ & 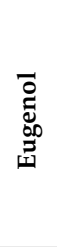 & 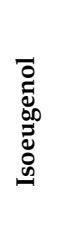 & $\begin{array}{l}\overrightarrow{0} \\
\text { 品 } \\
\text { 交 }\end{array}$ & 㞼 & $\sum_{i=1}^{m}$ & $\frac{\bar{\rho}}{\frac{\pi}{\pi}}$ & $\sum_{\substack{1 \\
\text { ம }}}^{\underbrace{}_{1}}$ & 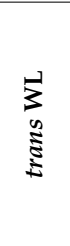 & 3 & 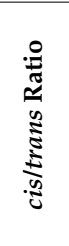 & 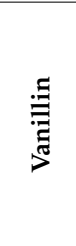 & 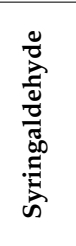 & 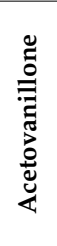 & 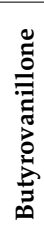 \\
\hline Staves & \multirow{6}{*}{$\begin{array}{l}225 \mathrm{~L} \\
\text { barrel } \\
\text { surface }\end{array}$} & \multirow{6}{*}{120} & \multirow{6}{*}{ 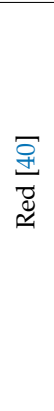 } & \multirow{6}{*}{$\begin{array}{c}\text { Alternative woods } \\
\text { Q.pyrenaica } \\
\text { traditional } \\
\text { seasoning } \\
\text { accelerated } \\
\text { seasoning } \\
\text { traditional } \\
\text { seasoning } \\
\text { accelerated } \\
\text { seasoning } \\
\text { traditional } \\
\text { seasoning } \\
\text { accelerated } \\
\text { seasoning } \\
\end{array}$} & 16 & 76 & 13 & 15 & 51 & 31 & 92 & 48 & 146 & 127 & 2491 & 73 & 662 & 9.1 & 225 & 523 & $\mathrm{~ns}$ & ns \\
\hline $\begin{array}{c}190^{\circ} \mathrm{C} \text { for } \\
10 \mathrm{~min}\end{array}$ & & & & & 19 & 13 & 16 & 14 & 75 & 33 & 68 & 98 & 207 & 136 & 3982 & 109 & 1442 & 13 & 188 & 432 & ns & ns \\
\hline \multirow{2}{*}{$\begin{array}{c}200^{\circ} \mathrm{C} \text { for } \\
15 \mathrm{~min}\end{array}$} & & & & & 24 & 45 & 22 & 13 & 45 & 27 & 78 & 136 & 622 & 250 & 4296 & 84 & 703 & 8.3 & 415 & 965 & $\mathrm{~ns}$ & ns \\
\hline & & & & & 33 & 1.6 & 29 & 24 & 76 & 41 & 153 & 13667 & 2135 & 323 & 7822 & 140 & 2342 & 17 & 326 & 918 & $\mathrm{~ns}$ & ns \\
\hline \multirow{2}{*}{$\begin{array}{c}210^{\circ} \mathrm{C} \text { for } \\
20 \mathrm{~min}\end{array}$} & & & & & 33 & 31 & 33 & 16 & 38 & 38 & 146 & 232 & 473 & 446 & 4224 & 90 & 314 & 3.5 & 584 & 1456 & ns & ns \\
\hline & & & & & 42 & 1.9 & 36 & 11 & 68 & 45 & 150 & 990 & 993 & 452 & 6177 & 215 & 2445 & 11 & 504 & 1234 & $\mathrm{~ns}$ & ns \\
\hline \multirow{2}{*}{$\begin{array}{c}200^{\circ} \mathrm{C} \text { for } \\
35 \mathrm{~min}\end{array}$} & \multirow{2}{*}{$\begin{array}{l}225 \mathrm{~L} \\
\text { barrel } \\
\text { surface }\end{array}$} & \multirow[t]{2}{*}{180} & \multirow{2}{*}{$\frac{\sigma}{\widetilde{D}}$} & $\begin{array}{l}\text { Alternative woods } \\
\text { Q. pyrenaica } \\
\text { Traditional }\end{array}$ & 43.4 & 2.84 & 41 & 54 & 54 & 72 & 192 & 14262 & 2163 & 377 & 2485 & 99 & 588 & 5.9 & 740 & 1912 & $\mathrm{~ns}$ & ns \\
\hline & & & & $\begin{array}{l}\text { Querus } \\
\text { Q. alba } \\
\text { O. petraea }\end{array}$ & $\begin{array}{l}44.3 \\
36.5\end{array}$ & $\begin{array}{l}2.68 \\
3.39\end{array}$ & $\begin{array}{l}34 \\
55\end{array}$ & $\begin{array}{l}31 \\
40\end{array}$ & $\begin{array}{l}36 \\
29\end{array}$ & $\begin{array}{l}71 \\
64\end{array}$ & $\begin{array}{l}184 \\
184\end{array}$ & $\begin{array}{l}13582 \\
8981\end{array}$ & $\begin{array}{l}1802 \\
2063\end{array}$ & $\begin{array}{l}305 \\
372\end{array}$ & $\begin{array}{l}1602 \\
1846\end{array}$ & $\begin{array}{l}64 \\
12\end{array}$ & $\begin{array}{l}466 \\
26\end{array}$ & $\begin{array}{l}7.24 \\
2.11\end{array}$ & $\begin{array}{l}613 \\
938\end{array}$ & $\begin{array}{l}1716 \\
2304\end{array}$ & $\begin{array}{l}\text { ns } \\
\text { ns }\end{array}$ & $\begin{array}{l}\text { ns } \\
\text { ns }\end{array}$ \\
\hline
\end{tabular}

Dosage: 2251 barrel surface $=$ The amount of oak chips and staves required to reproduce the surface/volume ratio of a barrel of 225 L Acronyms: 4-EG: 4-Ethylguaiacol; 4-MG: 4-Methylguaiacol; 4-VG: 4-Vinylguaiacol; trans WL: trans lactone (trans- $\beta$-Methyl- $\gamma$-octalactone); cis WL: cis lactone (trans- $\beta$-Methyl- $\gamma$-octalactone); ns: not studied; nd: not detected; nq:
not quantified. 
De Rosso et al., 2009 [74] studied the volatile composition of red wines aged in barrels of different alternative woods (acacia, chestnut, cherry and mulberry) and Q. petraea for 9 months and observed significant differences in some of the compounds. In the case of volatile phenols, it was found that the wines aged in acacia barrels had a higher content of 4-EG (3250 $\mu \mathrm{g} / \mathrm{L})$, which contributes phenolic, smoky and leathery notes, than the rest of the wines aged in the other barrels. Wines aged in acacia and chestnut barrels were characterised by a higher eugenol content $(21 \mu \mathrm{g} / \mathrm{L}$ and $26 \mu \mathrm{g} / \mathrm{L}$, respectively), which contributes clove, honey, spicy and cinnamon aromas, compared to wines aged in Q. petraea barrels $(18 \mu \mathrm{g} / \mathrm{L})$. These results are consistent with the analysis of toasted wood, where it was observed that chestnut and acacia wood had higher contents of this compound than $Q$. petraea. However, wines aged in Q. petraea barrels were characterised by a higher content of certain compounds, such as furfural and 5-MF. In contrast, the use of chestnut barrels contributed more vanilla to the wines than $Q$. petraea barrels. In addition, they observed that wines aged in mulberry barrels showed a significant decrease in fruity notes such as ethyl esters and other compounds, and yielded compounds considered aroma defects such as ethylphenol to the wine. In this study, they concluded that the wines studied could be differentiated quantitatively and qualitatively [74]. Thus, wines aged in Q. petraea barrels carried aromas of caramel and toasted almonds and wines aged in acacia and chestnut barrels gave more woody and spicy aromas, such as clove, smoke and vanilla. Therefore, it can be said that the aromas mostly found in the wines were the same as in the wood.

The number of literature references found was more abundant for 12-month ageing [29,75,76]. Kozlovic et al., 2010 [76] evaluated the aromatic composition of white wines aged in acacia barrels from two different geographical areas (Medjimurjey and Istria) against wines aged in Q. petraea barrels. The results showed a significant increase after 12 months in the content of furfural, 5-MF, guaiacol, eugenol and trans isoeugenol in all Malvasia white wines aged in acacia and oak barrels. After 12 months of ageing, clear differences were observed between the wines aged with these two types of wood. Thus, it was found that wines aged in acacia wood barrels were characterised by significantly higher guaiacol amounts than wines aged in Q. petraea barrels. In addition, other volatile phenols such as o-cresol, p-cresol and m-cresol, not found in wines aged in Q. petraea barrels, were also found in wines aged in acacia wood. On the other hand, the wines aged in Q. petraea barrels had more lactones. From the sensory analysis they were able to extract that the wines aged in acacia barrels were the best scoring wines.

In general, wines aged in Q. pyrenaica barrels were characterised by high levels of eugenol, guaiacol and other volatile phenols [29]. Regarding compounds such as cis lactone or maltol, the behaviour of $Q$. pyrenaica wood was very similar to that of $Q$. alba. As for phenolic aldehydes and ketones, the levels of $Q$. pyrenaica wines were intermediate between those aged in Q. petraea and Q. alba, with few significant differences. Another 2014 study by this group [75], very similar to that of De Rosso et al., 2009 [74], but after 12 months of ageing, evaluated wines aged in Q. petraea, acacia, chestnut, cherry and ash barrels. They found that phenolic aldehydes in wines aged in ash barrels, as in the studies on wood chips, had higher vanillin content than wines aged in the other barrels. Similarly, wines aged in ash barrels, together with those aged in chestnut barrels, were the richest in acetovanillone. Therefore, these wines were characterised by a higher content of volatile compounds that can provide vanilla aromas. Wines aged in chestnut barrels were also richer in butyrovanillone, and those aged in cherry were richer in syringaldehyde. As far as lactones are concerned, the results obtained in wines were similar to those found in the works discussed above, with wines aged with Q. petraea having the highest lactone content, as expected from the results observed in wood. In terms of furanic compounds, the chestnut barrels were the ones that contributed the most furfural (Table 5), as well as high 5-HMF contents in this compound similar to the Q. petraea barrels. In contrast, acacia and Q. petraea barrels contributed higher 5-MF contents, although much higher in the traditional barrels, 450 and $842 \mu \mathrm{g} / \mathrm{L}$, respectively. Finally, the wines aged in ash and acacia barrels had more than twice the maltol content, around $300 \mu \mathrm{g} / \mathrm{L}$, than the other 
wines. Furthermore, from the sensory analysis, it was observed that the wines aged in cherry barrels for more than 6 months were the ones with the worst scores, so this wood was more suitable for short ageing times [75].

There are also studies of the aromatic compounds of red wines aged in Q. pyrenaica and Q. faginea barrels compared to traditional barrels for 21 months, showing that in general, the wines aged in $Q$. alba barrels had higher aroma content than the rest of the wines aged in $Q$. pyrenaica, Q. faginea, Q. robur and Q. petraea barrels $[77,78]$. Therefore, for longer ageing, it seems that American oak barrels are more optimal, if a higher contribution of spicy aromas (due to guaiacol and eugenol), toasted nuts and caramel (due to furanic compounds), coconut and wood aromas (cis lactone) and vanilla aromas (vanillin and syringaldehyde) is sought. The $Q$. pyrenaica and $Q$. faginea woods were chemically similar to each other and to the traditional woods. However, from a sensory point of view, the wines aged in Q. faginea barrels were the worst evaluated and therefore seem to lack cooperage interest.

\subsection{Aging of Wines with Chips and Staves from Traditional and Alternative Woods}

The use of chips and staves to accelerate the ageing processes of wines, through a faster release of wood compounds, is a technique that has been widely used for years. As with barrels, the use of oak chips and staves, as well as other alternative woods, was studied in different studies with the aim of identifying those compounds that allow wines to be differentiated according to the volatile compounds and their concentration released by each type of wood. Fernández de Simón et al., 2010 [40] observed that wines aged in contact with staves provided a higher concentration of volatile compounds than wines aged with chips, although the release of the compounds from the wood into the wine was slower in the case of staves. This study was carried out on Q. pyrenaica wood, and the greatest differences were observed in trans isoeugenol, guaiacol, cis and trans lactones, eugenol, syringol, vanillin and maltol. Another study carried out by Santos et al., 2019 [79], in which chips from Q. petraea and Q. alba oak wood and alternative acacia and cherry woods were added, showed differences in the volatile composition of the different wines after 20 days in contact with the chips. The greatest differences were seen in the phenolic aldehyde group, where the wines to which oak chips were added had higher vanillin and syringaldehyde contents than the wines to which alternative wood chips were added. Differences were also seen in other compounds, although minor, such as cis lactone, furfural and 5-methylfurfural.

Rodríguez-Bencomo et al., 2009 [31] evaluated the volatile composition of red wines aged for 2 months with chips of Q. pyrenaica, Q. petraea, Q. petraea and Q. robur and Q. alba. These authors observed that wines aged with $Q$. pyrenaica had a higher content of furanic compounds (furfural and 5-methylfurfural) and eugenol than wines aged with traditional oak chips. In contrast, wines aged with $Q$. alba chips differed from the rest by having higher cis lactone, vanillin and syringaldehyde content. Fernández de Simón et al., 2010 [6] also studied the effect of using Q. pyrenaica, Q. alba and Q. petraea chips but aged for 6 months on the volatile composition of red wines. The results obtained showed that the volatile composition was very similar in the three types of wines, with only small differences in the content of cis lactone and eugenol, the content of both compounds being higher in the wines with Q. pyrenaica than those macerated with Q. alba and Q. petraea. These authors carried out the same study with staves, where the differences in cis lactone and eugenol content were greater than in the chips.

Q. humboldtii wood in contact with wine was studied after 3 months with chips in red wines and compared with Q. petraea and Q. alba chips [7], showing that the aromas of wines aged with this alternative wood differed quantitatively from those aged with traditional woods. Wines macerated with $Q$. humboldtii were found to have higher contents of 5-MF, guaiacol, isoeugenol and syringol. In contrast, these wines were lower in 5-HMF, cis and trans lactone and vanillin than wines macerated with $Q$. alba and $Q$. petraea oak. These differences in the chemical analysis were also observed in the sensory analysis, where it 
was found that the wines macerated with Colombian oak were characterised by woody and smoky aromas compared to the other wines.

\section{Conclusions}

The volatile composition of Quercus alternative woods compared to traditional oak species only differs quantitatively, as the same compounds have been found. The volatile composition concentration of $Q$. pyrenaica varies widely depending on cooperage treatments, origin and other factors. The volatile composition of $Q$. pyrenaica wood can be considered similar to traditional oak species used in winemaking and is probably very interesting for its contribution of coconut, spice, clove, caramel to almond and clove notes due to its higher content of cis lactone, eugenol, $4-\mathrm{VG}$ and furanic compounds. These results have also been confirmed in studies carried out on wines aged in barrels and with pieces of wood with $Q$. pyrenaica. The volatile composition of $Q$. faginea wood and of the wines aged seems to be qualitatively and quantitative similar to that of the traditional oak species. However, the wines aged with $Q$. faginea were the worst evaluated from a sensory point of view, so that wood seems to be of no interest for wine aging. Q. humboldtii wood seems to be an interesting wood due to its high contents of 5-MF, guaiacol, 4-VG, cis isoeugenol and syringol, but poor in furfural, 5-HMF, cis and trans lactones. Wines aged with this wood corroborated the results of the wood.

Acacia, chestnut, cherry and ash show differences not only quantitatively but also qualitatively, presenting compounds that are not found in Quercus woods and not having in their composition compounds as important as cis and trans lactones. All these woods except ash show some compounds that are not found in any other woods. Toasting causes an increase in the concentrations of most of the volatile compounds, and this increase is especially important in acacia, chestnut and ash woods. Thus, toasted acacia wood shows high contents of guaiacol, eugenol, isoeugenol, syringol, furanic compounds, syringaldehyde and acetovanillone. Chestnut wood after medium toasting is rich in volatile phenols, furanic compounds and phenolic aldehydes/phenyl ketones. In addition, ash wood after medium toasting has high contents of guaiacol, isoeugenol, syringol, maltol, vanillin, syringaldehyde and acetovanillone; however, it is rather low in furfural. American ash appears to be more aromatic than European ash. Acacia, chestnut, cherry and ash woods after medium toasting have higher lignin derivatives than Quercus wood. In addition, acacia and chestnut woods are also richer in lipid and carbohydrate derivatives than traditional oaks woods, while cherry and ash woods are relatively poor in these compounds. In the case of wines, those made from acacia and chestnut wood are richer in eugenol. In addition, those made from chestnut wood also stand out for their high vanillin content and those made from acacia wood for their higher 4-EG content. On the other hand, wines aged in ash wood are characterised by being richer in vanillin and acetovanillone. Mulberry wood does not seem to be of great interest for the aging of wines, since it decreases the fruity notes and increases the compounds that contribute negative notes.

Author Contributions: Conceptualization, A.M.M.-G. and M.d.A.-S.; formal analysis, A.M.M.-G., M.d.A.-S., I.N. and R.d.B.-G.; investigation, A.M.M.-G., M.d.A.-S., I.N. and R.d.B.-G.; writingoriginal draft preparation, A.M.M.-G.; writing-review and editing, A.M.M.-G., M.d.A.-S., I.N. and R.d.B.-G.; supervision, M.d.A.-S. and I.N.; project administration, M.d.A.-S. and I.N.; funding acquisition, M.d.A.-S. and I.N. All authors have read and agreed to the published version of the manuscript.

Funding: This study was financed by Junta de Castilla and León VA028U16, MINECO (AGL201454602-P and AGL2017-87373-C3-2-R) and Interreg Spain-Portugal for Iberphenol Project.

Data Availability Statement: For data request, the contact of the corresponding author is present in the affiliation part of each referenced manuscript.

Conflicts of Interest: The authors declare no conflict of interest. 


\section{References}

1. Tao, Y.; García, J.F.; Sun, D.W. Advances in wine aging technologies for enhancing wine quality and accelerating wine aging process. Crit. Rev. Food Sci. Nutr. 2014, 54, 817-835. [CrossRef] [PubMed]

2. Jackson, R.S. Wine science: Principles and applications. In Oak and Cooperage; Academic Press: New York, NY, USA, 1994; pp. 299-311.

3. Cadahía, E.; Muñoz, L.; De Simón, B.F.; García-Vallejo, M.C. Changes in low molecular weight phenolic compounds in Spanish, French, and American oak woods during natural seasoning and toasting. J. Agric. Food Chem. 2001, 49, 1790-1798. [CrossRef] [PubMed]

4. Garde-Cerdán, T.; Ancín-Azpilicueta, C. Review of quality factors on wine ageing in oak barrels. Trends Food Sci. Technol. 2006, 17, 438-447. [CrossRef]

5. Martínez-Gil, A.; del Alamo-Sanza, M.; Sánchez-Gómez, R.; Nevares, I. Alternative woods in enology: Characterization of tannin and low molecular weight phenol compounds with respect to traditional oak woods. A review. Molecules 2020, $25,1474$. [CrossRef]

6. Fernández de Simón, B.; Cadahía, E.; Muiño, I.; del Álamo, M.; Nevares, I. Volatile composition of toasted oak chips and staves and of red wine aged with them. Am. J. Enol. Vitic. 2010, 61, 157-165.

7. Martínez-Gil, A.M.; del Alamo-Sanza, M.; Gutiérrez-Gamboa, G.; Moreno-Simunovic, Y.; Nevares, I. Volatile composition and sensory characteristics of Carménère wines macerating with Colombian (Quercus humboldtii) oak chips compared to wines macerated with American (Q. alba) and European (Q. petraea) oak chips. Food Chem. 2018, 266, 90-100. [CrossRef]

8. Caldeira, I.; Anjos, O.; Belchior, A.P.; Canas, S. Sensory impact of alternative ageing technology for the production of wine brandies. Cienc. Tec. Vitivinic. 2017, 32, 12-22. [CrossRef]

9. Cruz, S.; Canas, S.; Belchior, A.P. Effect of ageing system and time on the quality of wine brandy aged at industrial-scale. Cienc. Tec. Vitivinic. 2013, 27, 83-93.

10. Fernández de Simón, B.; Cadahía, E. Utilización del Roble Español en el Envejecimiento de Vinos: Comparación con Roble Francés y Americano; Instituto Nacional de Investigación y Tecnología Agraria y Alimentaria Ministerio de Educación y Ciencia: Madrid, Spain, 2004.

11. Cadahía, E.; Fernández de Simón, B.; Poveda, P.; Sanz, M. Utilización de Quercus Pyrenaica Willd. de Castilla y León en el Envejecimiento de Vinos. Comparación con Roble Francés y Americano; Instituto Nacional de Investigación y Tecnología Agraria y Alimentaria Ministerio de Educación y Ciencia: Madrid, Spain, 2008.

12. Martínez-Gil, A.; del Alamo-Sanza, M.; Sánchez-Gómez, R.; Nevares, I. Different Woods in Cooperage for Oenology: A Review. Beverages 2018, 4, 94. [CrossRef]

13. Chira, K.; Teissedre, P.-L. Chemical and sensory evaluation of wine matured in oak barrel: Effect of oak species involved and toasting process. Eur. Food Res. Technol. 2015, 240, 533-547. [CrossRef]

14. Cadahía, E.; Varea, S.; Muñoz, L.; Fernández de Simón, B.; García-Vallejo, M.C. Evolution of Ellagitannins in Spanish, French, and American Oak Woods during Natural Seasoning and Toasting. J. Agric. Food Chem. 2001, 49, 3677-3684. [CrossRef] [PubMed]

15. Guchu, E.; Díaz-Maroto, M.C.; Pérez-Coello, M.S.; González-Viñas, M.A.; Cabezudo Ibáñez, M.D. Volatile composition and sensory characteristics of Chardonnay wines treated with American and Hungarian oak chips. Food Chem. 2006, 99, 350-359. [CrossRef]

16. Díaz-Maroto, M.C.; Guchu, E.; Castro-Vázquez, L.; de Torres, C.; Pérez-Coello, M.S. Aroma-active compounds of American, French, Hungarian and Russian oak woods, studied by GC-MS and GC-O. Flavour Fragr. J. 2008, 23, 93-98. [CrossRef]

17. Mosedale, J.R.; Ford, A. Variation of the Flavour and Extractives of European Oak Wood from Two French Forests. J. Sci. Food Agric. 1996, 70, 273-287. [CrossRef]

18. Prida, A.; Puech, J.-L. Influence of Geographical Origin and Botanical Species on the Content of Extractives in American, French, and East European Oak Woods. J. Agric. Food Chem. 2006, 54, 8115-8126. [CrossRef]

19. Sanz, M.; Fernández de Simón, B.; Cadahía, E.; Esteruelas, E.; Muñoz, Á.M.; Hernández, M.T.; Estrella, I. Polyphenolic profile as a useful tool to identify the wood used in wine aging. Anal. Chim. Acta 2012, 732, 33-45. [CrossRef]

20. Jordão, A.M.; Lozano, V.; Correia, A.C.; Ortega-Heras, M.; González-SanJosé, M.L. Comparative analysis of volatile and phenolic composition of alternative wood chips from cherry, acacia and oak for potential use in enology. BIO Web Conf. 2016, 7, 02012. [CrossRef]

21. Canas, S.; Leandro, M.C.; Spranger, M.I.; Belchior, A.P. Influence of botanical species and geographical origin on the content of low molecular weight phenolic compounds of woods used in Portuguese cooperage. Holzforschung 2000, 54, 255-261. [CrossRef]

22. Sanz, M.; Cadahía, E.; Esteruelas, E.; Muñoz, Á.M.; Fernández De Simón, B.; Hernández, T.; Estrella, I. Phenolic compounds in cherry (Prunus avium) heartwood with a view to their use in cooperage. J. Agric. Food Chem. 2010, 58, 4907-4914. [CrossRef]

23. Fernández de Simón, B.; Esteruelas, E.; Muñoz, À.M.; Cadahía, E.; Sanz, M. Volatile compounds in acacia, chestnut, cherry, ash, and oak woods, with a view to their use in cooperage. J. Agric. Food Chem. 2009, 57, 3217-3227. [CrossRef]

24. Culleré, L.; Fernández de Simón, B.; Cadahía, E.; Ferreira, V.; Hernández-Orte, P.; Cacho, J. Characterization by gas chromatography-olfactometry of the most odor-active compounds in extracts prepared from acacia, chestnut, cherry, ash and oak woods. LWT -Food Sci. Technol. 2013, 53, 240-248. [CrossRef]

25. Perez-Coello, M.S.; Díaz-Maroto, M.C. Volatile Compounds and Wine Aging. In Wine Chemistry and Biochemistry; Moreno-Arribas, M.V., Polo, M.C., Eds.; Springer: Berlin/Heidelberg, Germany, 2009; pp. 295-307, ISBN 9780387741161. 
26. Sánchez-Gómez, R.; del Alamo-Sanza, M.; Nevares, I. Volatile composition of oak wood from different customised oxygenation wine barrels: Effect on red wine. Food Chem. 2020, 329, 127181. [CrossRef] [PubMed]

27. Chatonnet, P.; Boidron, J.N.; Pons, M. Maturation of red wines in oak barrels: Evolution of some volatile compounds and their aromatic impact. Sci. Aliment. 1990, 10, 565-587.

28. Marco, J.; Artajona, J.; Larrechi, M.S.; Rius, F.X. Relationship Between Geographical Origin and Chemical Composition of Wood for Oak Barrels. Am. J. Enol. Vitic. 1994, 45, 192-200.

29. De Simón, B.F.; Cadahía, E.; Sanz, M.; Poveda, P.; Perez-Magariño, S.; Ortega-Heras, M.; González-Huerta, C. Volatile compounds and sensorial characterization of wines from four spanish denominations of origin, aged in Spanish Rebollo (Quercus pyrenaica Willd.) oak wood barrels. J. Agric. Food Chem. 2008, 56, 9046-9055. [CrossRef] [PubMed]

30. Waterhouse, A.L.; Towey, J.P. Oak lactone isomer ratio distinguishes between wine fermented in American and French oak barrels. J. Agric. Food Chem. 1994, 42, 1971-1974. [CrossRef]

31. Rodríguez-Bencomo, J.J.; Ortega-Heras, M.; Pérez-Magariño, S.; González-Huerta, C. Volatile compounds of red wines macerated with Spanish, American, and French Oak chips. J. Agric. Food Chem. 2009, 57, 6383-6391. [CrossRef]

32. Culleré, L.; Escudero, A.; Cacho, J.; Ferreira, V. Gas Chromatography-Olfactometry and Chemical Quantitative Study of the Aroma of Six Premium Quality Spanish Aged Red. J. Agric. Food Chem. 2004, 53, 1653-1660. [CrossRef]

33. Pereira, V.; Cacho, J.; Marques, J.C. Volatile profile of Madeira wines submitted to traditional accelerated ageing. Food Chem. 2014, 162, 122-134. [CrossRef]

34. Herrero, P.; Sáenz-Navajas, M.P.; Avizcuri, J.M.; Culleré, L.; Balda, P.; Antón, E.C.; Ferreira, V.; Escudero, A. Study of Chardonnay and Sauvignon blanc wines from D.O.Ca Rioja (Spain) aged in different French oak wood barrels: Chemical and aroma quality aspects. Food Res. Int. 2016, 89, 227-236. [CrossRef]

35. Caldeira, I.; de Sousa, R.B.; Belchior, A.P.; Climaco, M.C. A sensory and chemical approach to the aroma of wooden agend Lourinha wine brandy. Cienc. Tec. Vitivinic. 2008, 23, 97-110.

36. Lopez, R.; Aznar, M.; Cacho, J.; Ferreira, V. Determination of minor and trace volatile compounds in wine by solid-phase extraction and gas chromatography with mass spectrometric detection. J. Chromatogr. A 2002, 966, 167-177. [CrossRef]

37. Cutzach, I.; Chatonnet, P.; Henry, R.; Dubourdieu, D. Identifying new volatile compounds in toasted oak. J. Agric. Food Chem. 1999, 47, 1663-1667. [CrossRef] [PubMed]

38. Brown, R.C.; Sefton, M.A.; Taylor, D.K.; Elsey, G.M. An odour detection threshold determination of all four possible stereoisomers of oak lactone in a white and a red wine. Aust. J. Grape Wine Res. 2006, 12, 115-118. [CrossRef]

39. Juan, F.S.; Cacho, J.; Ferreira, V.; Escudero, A. Aroma chemical composition of red wines from different price categories and its relationship to quality. J. Agric. Food Chem. 2012, 60, 5045-5056. [CrossRef] [PubMed]

40. Fernández de Simón, B.; Cadahía, E.; del Álamo, M.; Nevares, I. Effect of size, seasoning and toasting in the volatile compounds in toasted oak wood and in a red wine treated with them. Anal. Chim. Acta 2010, 660, 211-220. [CrossRef] [PubMed]

41. Sefton, M.S.; Francis, I.L.; Pocock, K.F.; Williams, P.J. The influence of natural seasoning on the concentrations of eugenol, vanillin, and cis- and trans- $\beta$-methyl- $\gamma$-octalactone extracted from French and American oakwood. Sci. Aliment. 1993, 13, $629-643$.

42. Martínez-Gil, A.M.; del Alamo-Sanza, M.; Nevares, I.; Sánchez-Gómez, R.; Gallego, L. Effect of size, seasoning and toasting level of Quercus pyrenaica Willd. wood on wine phenolic composition during maturation process with micro- oxygenation. Food Res. Int. 2020, 128, 108703. [CrossRef]

43. Chira, K.; Teissedre, P.-L.L. Extraction of oak volatiles and ellagitannins compounds and sensory profile of wine aged with French wine woods subjected to different toasting methods: Behaviour during storage. Food Chem. 2013, 140, 168-177. [CrossRef]

44. Chatonnet, P.; Boidron, J.; Pons, M. Incidence du traitement thermique du bois de chêne sur sa composition chimique 2e partie: Évolution de certains composés en fonction de l'intensité de brûlage. J. Int. Sci. Vigne Vin 1989, 23, 223-250. [CrossRef]

45. Chatonnet, P. Productos alternativos a la crianza en barrica. $3^{\mathrm{a}}$ parte: El tostado. In Proceedings of the IV Encuentro Enológico: Crianza en Barricas y Otras Alternativas; Fundación para la Cultura del Vino: Madrid, Spain, 2007; p. 5.

46. Dumitriu, G.D.; López de Lerma, N.; Zamfir, C.I.; Cotea, V.V.; Peinado, R.A. Volatile and phenolic composition of red wines subjected to aging in oak cask of different toast degree during two periods of time. LWT-Food Sci. Technol. 2017, 86, 643-651. [CrossRef]

47. Prida, A.; Chatonnet, P. Impact of Oak-Derived Compounds on the Olfactory Perception of Barrel-Aged Wines. Am. J. Enol. Vitic. 2010, 61, 408-413.

48. Reazin, G.H. Chemical mechanisms of whiskey maturation. Am. J. Enol. Vitic. 1981, 32, 283-289.

49. Otsuka, K.; Sato, K.; Yamashita, T. Structure of a precursor of beta methyl beta y gamma octalactone, an aging flavor compound of distilled liquors. J. Ferment. Technol. 1980, 58, 395-398.

50. Díaz-Plaza, E.M.; Reyero, J.R.; Pardo, F.; Alonso, G.L.; Salinas, M.R. Influence of oak wood on the aromatic composition and quality of wines with different tannin contents. J. Agric. Food Chem. 2002, 50, 2622-2626. [CrossRef] [PubMed]

51. Cerdán, T.G.; Rodríguez Mozaz, S.; Ancín Azpilicueta, C. Volatile composition of aged wine in used barrels of French oak and of American oak. Food Res. Int. 2002, 35, 603-610. [CrossRef]

52. Bautista-Ortín, A.B.; Lencina, A.G.; Cano-López, M.; Pardo-Mínguez, F.; López-Roca, J.M.; Gómez-Plaza, E. The use of oak chips during the ageing of a red wine in stainless steel tanks or used barrels: Effect of the contact time and size of the oak chips on aroma compounds. Aust. J. Grape Wine Res. 2008, 14, 63-70. [CrossRef] 
53. Rubio-Bretón, P.; Lorenzo, C.; Salinas, M.R.; Martínez, J.; Garde-Cerdán, T. Influence of oak barrel aging on the quality of red wines. In Oak: Ecology, Types and Management; Chuteira, C.A., Grão, A.B., Eds.; Nova Science Publishers, Inc.: Hauppauge, NY, USA, 2013; pp. 59-86.

54. Rubio-Bretón, P.; Garde-Cerdán, T.; Martínez, J. Use of Oak Fragments during the Aging of Red Wines. Effect on the Phenolic, Aromatic, and Sensory Composition of Wines as a Function of the Contact Time with the Wood. Beverages 2018, 4, 102. [CrossRef]

55. Del Alamo-Sanza, M.; Nevares, I.; Martínez-Gil, A.; Rubio-Bretón, P.; Garde-Cerdán, T. Impact of long bottle aging (10 years) on volatile composition of red wines micro-oxygenated with oak alternatives. LWT -Food Sci. Technol. 2019, 101, 395-403. [CrossRef]

56. Ortega-Heras, M.; González-Huerta, C.; Herrera, P.; González-Sanjosé, M.L. Changes in wine volatile compounds of varietal wines during ageing in wood barrels. Anal. Chim. Acta 2004, 513, 341-350. [CrossRef]

57. Cadahía, E.; Fernández de Simón, B.; Sanz, M.; Poveda, P.; Colio, J. Chemical and chromatic characteristics of Tempranillo, Cabernet Sauvignon and Merlot wines from DO Navarra aged in Spanish and French oak barrels. Food Chem. 2009, 115, 639-649. [CrossRef]

58. Cadahía, E.; Fernández de Simón, B.; Vallejo, R.; Sanz, M.; Broto, M. Volatile compound evolution in Spanish oak wood (Quercus petraea and Quercus pyrenaica) during natural seasoning. Am. J. Enol. Vitic. 2007, 58, 163-172.

59. Fernández de Simón, B.; Sanz, M.; Cadahía, E.; Poveda, P.; Broto, M. Chemical characterization of oak heartwood from Spanish forests of Quercus pyrenaica (Wild.). Ellagitannins, low molecular weight phenolic, and volatile compounds. J. Agric. Food Chem. 2006, 54, 8314-8321. [CrossRef] [PubMed]

60. Alañón, M.E.; Pérez-Coello, M.S.; Díaz-Maroto, I.J.; Martín-Alvarez, P.J.; Vila-Lameiro, P.; Díaz-Maroto, M.C. Influence of geographical location, site and silvicultural parameters, on volatile composition of Quercus pyrenaica Willd. wood used in wine aging. For. Ecol. Manag. 2011, 262, 124-130. [CrossRef]

61. Alañón, M.E.; Castro-Vázquez, L.; Díaz-Maroto, M.C.; Pérez-Coello, M.S. Aromatic potential of Castanea sativa Mill. Compared to Quercus species to be used in cooperage. Food Chem. 2012, 130, 875-881. [CrossRef]

62. Caldeira, I.; Clímaco, M.C.; Bruno De Sousa, R.; Belchior, A.P. Volatile composition of oak and chestnut woods used in brandy ageing: Modification induced by heat treatment. J. Food Eng. 2006, 76, 202-211. [CrossRef]

63. Jordao, A.M.; Ricardo-da-Silva, J.M.; Laureano, O. Comparison of volatile composition of cooperage oak wood of different origins (Quercus pyrenaica vs. Quercus alba and Quercus petraea). Mitt. Klost. 2005, 55, 22-31.

64. Cadahía, E.; Fernández de Simón, B.; Jalocha, J. Volatile compounds in Spanish, French, and American oak woods after natural seasoning and toasting. J. Agric. Food Chem. 2003, 51, 5923-5932. [CrossRef]

65. Fernández De Simõn, B.; Sanz, M.; Cadahía, E.; Esteruelas, E.; Muñoz, A.M. Nontargeted GC-MS approach for volatile profile of toasting in cherry, chestnut, false acacia, and ash wood. J. Mass Spectrom. 2014, 49, 353-370. [CrossRef]

66. Fernández De Simón, B.; Muiño, I.; Cadahía, E. Characterization of volatile constituents in commercial oak wood chips. J. Agric. Food Chem. 2010, 58, 9587-9596. [CrossRef]

67. Jordão, A.M.; Ricardo-Da-Silva, J.M.; Laureano, O.; Adams, A.; Demyttenaere, J.; Verhé, R.; De Kimpe, N. Volatile composition analysis by solid-phase microextraction applied to oak wood used in cooperage (Quercus pyrenaica and Quercus petraea): Effect of botanical species and toasting process. J. Wood Sci. 2006, 52, 514-521. [CrossRef]

68. Doussot, F.; De Jéso, B.; Quideau, S.; Pardon, P. Extractives content in cooperage oak wood during natural seasoning and toasting; influence of tree species, geographic location, and single-tree effects. J. Agric. Food Chem. 2002, 50, 5955-5961. [CrossRef] [PubMed]

69. Wilkinson, K.L.; Prida, A.; Hayasaka, Y. Role of glycoconjugates of 3-methyl-4-hydroxyoctanoic acid in the evolution of oak lactone in wine during oak maturation. J. Agric. Food Chem. 2013, 61, 4411-4416. [CrossRef] [PubMed]

70. Chatonnet, P.; Cutzach, I.; Pons, M.; Dubourdieu, D. Monitoring toasting intensity of barrels by chromatographic analysis of volatile compounds from toasted oak wood. J. Agric. Food Chem. 1999, 47, 4310-4318. [CrossRef] [PubMed]

71. Flamini, R.; Dalla Vedova, A.; Cancian, D.; Panighel, A.; De Rosso, M. GC/MS-positive ion chemical ionization and MS/MS study of volatile benzene compounds in five different woods used in barrel making. J. Mass Spectrom. 2007, 42, 641-646. [CrossRef]

72. Alañón, M.E.; Marchante, L.; Alarcón, M.; Díaz-Maroto, I.J.; Pérez-Coello, M.S.; Díaz-Maroto, M.C. Fingerprints of acacia aging treatments by barrels or chips based on volatile profile, sensorial properties, and multivariate analysis. J. Sci. Food Agric. 2018, 18, 5795-5806. [CrossRef]

73. Alañón, M.E.; Schumacher, R.; Castro-Vázquez, L.; Díaz-Maroto, M.C.; Hermosín-Gutiérrez, I.; Pérez-Coello, M.S. Enological potential of chestnut wood for aging Tempranillo wines Part II: Phenolic compounds and chromatic characteristics. Food Res. Int. 2013, 51, 536-543. [CrossRef]

74. De Rosso, M.; Panighel, A.; Vedova, A.D.; Stella, L.; Flamini, R. Changes in chemical composition of a red wine aged in acacia, cherry, chestnut, mulberry, and oak wood barrels. J. Agric. Food Chem. 2009, 57, 1915-1920. [CrossRef]

75. Fernández de Simón, B.; Martínez, J.; Sanz, M.; Cadahía, E.; Esteruelas, E.; Muñoz, A.M.M. Volatile compounds and sensorial characterisation of red wine aged in cherry, chestnut, false acacia, ash and oak wood barrels. Food Chem. 2014, 147, 346-356. [CrossRef]

76. Kozlovic, G.; Jeromel, A.; Maslov, L.; Pollnitz, A.; Orlić, S. Use of acacia barrique barrels-Influence on the quality of Malvazija from Istria wines. Food Chem. 2010, 120, 698-702. [CrossRef]

77. Fernández De Simón, B.; Cadahía, E.; Jalocha, J. Volatile compounds in a Spanish red wine aged in barrels made of Spanish, French, and American oak wood. J. Agric. Food Chem. 2003, 51, 7671-7678. [CrossRef] [PubMed] 
78. Fernández De Simón, B.; Cadahía, E.; Hernández, T.; Estrella, I. Evolution of oak-related volatile compounds in a Spanish red wine during 2 years bottled, after aging in barrels made of Spanish, French and American oak wood. Anal. Chim. Acta 2006, 563, 198-203. [CrossRef]

79. Santos, F.; Correia, A.C.; Ortega-Heras, M.; García-Lomillo, J.; González-SanJosé, M.L.; Jordão, A.M.; Ricardo-da-Silva, J.M. Acacia, cherry and oak wood chips used for a short aging period of rosé wines: Effects on general phenolic parameters, volatile composition and sensory profile. J. Sci. Food Agric. 2019, 99, 3588-3603. [CrossRef] [PubMed]

80. Alañón, M.E.; Schumacher, R.; Castro-Vázquez, L.; Díaz-Maroto, I.J.; Díaz-Maroto, M.C.; Pérez-Coello, M. Enological potential of chestnut wood for aging Tempranillo wines part I: Volatile compounds and sensorial properties. Food Res. Int. 2013, 51, 325-334. [CrossRef] 